Research Paper

\title{
Avalonia, get bent! - Paleomagnetism from SW Iberia confirms the Greater Cantabrian Orocline
}

\author{
Bruno Daniel Leite Mendes ${ }^{\text {a, }}$, Daniel Pastor-Galán ${ }^{\text {b,c,d, }}{ }^{\text {, Mark J. Dekkers }}{ }^{\text {a }}$, Wout Krijgsman ${ }^{\text {a }}$ \\ ${ }^{a}$ Paleomagnetic Laboratory Fort Hoofddijk, Department of Earth Sciences, Utrecht University, Budapestlaan 17, 3584CD, the Netherlands \\ ${ }^{\mathrm{b}}$ Frontier Research Institute for Interdisciplinary Sciences, Tohoku University, Japan \\ ${ }^{c}$ Department Earth Science, Tohoku University, Japan \\ d Center for North East Asia Studies, Tohoku University, 980-8576, 41 Kawauchi, Aoba-ku, Sendai, Miyagi, Japan
}

\section{A R T I C L E I N F O}

Handling Editor: R. Damian Nance

\section{Keywords:}

Pangea

Variscan orogeny

Greater Cantabrian Orocline

Paleomagnetism

Central Iberian curve

\begin{abstract}
A B S T R A C T
The amalgamation of Pangea formed the contorted Variscan-Alleghanian orogen, suturing Gondwana and Laurussia during the Carboniferous. From all swirls of this orogen, a double curve in Iberia stands out, the coupled Cantabrian Orocline and Central Iberian curve. The Cantabrian Orocline formed at ca. 315-290 Ma subsequent to the Variscan orogeny. The formation mechanism of the Cantabrian Orocline is disputed, the most commonly proposed mechanisms include either (1) that south-westernmost Iberia would be an Avalonian (Laurussian) indenter or (2) that the stress field changed, buckling the orogen. In contrast, the geometry and kinematics of the Central Iberian curve are largely unknown. Whereas some authors defend both curvatures are genetically linked, others support they are distinct and formed at different times. Such uncertainty adds an extra layer of complexity to our understanding of the final stages of Pangea's amalgamation. To solve these issues, we study the late Carboniferous- early Permian vertical-axis rotations of SW Iberia with paleomagnetism. Our results show up to $70^{\circ}$ counterclockwise vertical-axis rotations during late Carboniferous times, concurring with the anticipated kinematics if SW Iberia was part of the southern limb of the Cantabrian Orocline. Our results do not allow the necessary penecontemporaneous clockwise rotations in Central Iberia to support a concomitant formation of both Cantabrian and Central Iberian curvature. The coherent rotation of both Gondwanan and Avalonian pieces of SW Iberia discards the Laurussian indenter hypothesis as a formation mechanism of the Cantabrian Orocline and confirms the Greater Cantabrian Orocline hypothesis. The Greater Cantabrian Orocline likely formed as a consequence of a change in the stress field during the late Carboniferous and extended beyond the Rheic Ocean suture affecting the margins of both Laurussia and Gondwana.
\end{abstract}

\section{Introduction}

Most orogens show a certain degree of curvature when observed in map-view. These curves can range from minor deflections of the orogen (i.e. kilometric deflections in thrust trends, Izquierdo-Llavall et al., 2018), to bends affecting the entire lithosphere (Li et al., 2012). The mechanisms that form curved mountain belts are extremely varied and include non-cylindrical collision(s), changes in stress field and/or basin architecture, terrain wrecks, and several others (Marshak, 2004; Johnston et al., 2013). Curved mountain belts' kinematics and their geodynamic consequences remain peculiar and engaging, despite being widespread around the globe. The kinematic classification of orogen curvature distinguishes two end members (Weil and Sussman, 2004; Johnston et al., 2013; Pastor-Galán et al., 2017a). The first includes primary arcs: orogenic curves in map view that pre-date the main orogenic event, for example an embayment. The second end member includes secondary oroclines: orogenic bends whose entire curvature is the product of bending/buckling an originally linear main orogen around a vertical axis (e.g. Eldredge et al., 1985). Progressive oroclines are all orogenic curves whose curvature is only partially due to vertical axis rotations (e.g. Meijers et al., 2017).

The late Paleozoic era is dominated by the amalgamation of Pangea (e.g. Stampfli et al., 2013), the latest continental superplate (e.g. Pastor-Galán et al., 2019). One of the main Pangea-forming collisions,

\footnotetext{
* Corresponding author.

E-mail address: b.daniel.lm@gmail.com (B.D. Leite Mendes).

Peer-review under responsibility of China University of Geosciences (Beijing).
} 
between Gondwana and Laurussia, resulted in the thousands of kilometers long and winding Variscan-Alleghanian orogen during the middle-to-late Devonian and Carboniferous (Fig. 1) (e.g. Stampfli et al., 2013; Ballèvre et al., 2014; Domeier and Torsvik., 2014; Martínez-Catalán et al., 2019). This contorted orogen has its most prominent curved structures in Iberia (Martínez-Catalán, 2012; Shaw et al., 2012; Weil et al., 2013): the Cantabrian Orocline, to the north, and the Central Iberian curve, to the south (Figs. 1 and 2a). The Cantabrian Orocline shows a nearly $180^{\circ}$ curvature running from Brittany (present day France), through the Bay of Biscay, into central Iberia. This well studied orocline formed at ca. 315-290 Ma after the main Variscan orogenic building phases in Iberia (e.g. Weil et al., 2019).

In contrast, the geometry and kinematics of the Central Iberian curve (Figs. 1 and 2a) are still under debate (e.g. Weil et al., 2019). Largely due to a lack of constraints, the proposed formation mechanisms are contradictory. Some authors consider that the Cantabrian Orocline and Central Iberian curve formed coevally as a coupled-orocline (e.g. Martínez-Catalán, 2011; Shaw et al., 2012). Other studies suggest that any vertical axis rotation in the Central Iberian curve must predate the formation of the Cantabrian Orocline (Pastor-Galán et al., 2016; Jacques et al., 2018a; Azor et al., 2019). Two of the suggested mechanisms are capable of explaining the available structural and paleomagnetic data (Fig. 3): (1) A mid-to-late Carboniferous indentation of Laurussia into Gondwana in SW Iberia and NW Africa (e.g. Lorenz and Nicholls, 1984; Simancas et al., 2013; Accotto et al., 2020); and (2) a late Carboniferous-early Permian change in the prevailing stress field due to plate reorganizations at the waning stages of the amalgamation of Pangea (e.g. Gutíerrez-Alonso et al., 2008; Martínez-Catalán, 2011; Pastor-Galán et al., 2015b). Following the second hypothesis, Pastor-Galán et al. (2015a) proposed the existence of a so-called Greater Cantabrian Orocline that would have bent the entire Variscan orogen around a vertical axis, including the previously formed Central Iberian curve. This large-scale curved structure would trespass the main lithospheric scale structures and the suture zone that separates the continental margins of Gondwana and Laurussia.

Here, we investigate the late Carboniferous-early Permian kinematics in Iberia through paleomagnetism. We focus on SW Iberia, encompassing

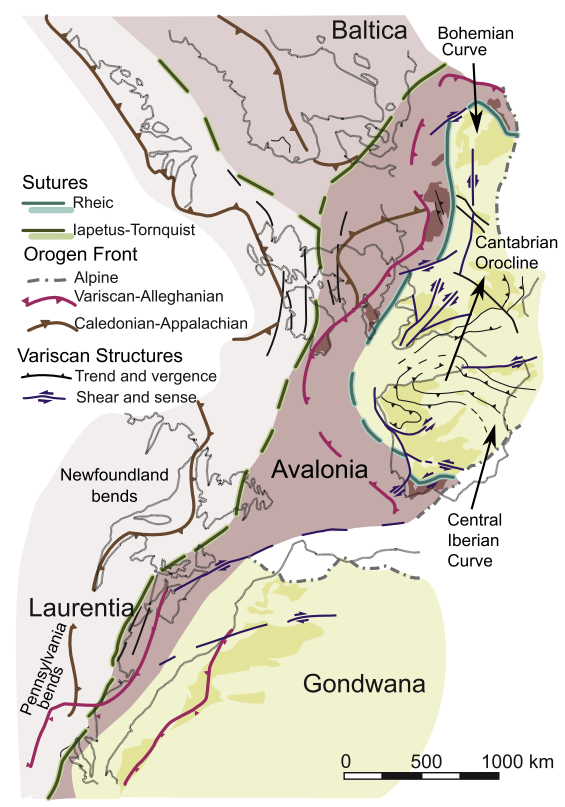

Fig. 1. Simplified paleogeographic map of the winding Variscan-Alleghanian belt at the time before the break-up of Pangea. Terranes with Gondwanan affinity are indicated in yellow tones, while terranes with Laurussian affinity are in red tones. Present-day European and African Variscan outcrops are darker (modified after Martínez-Catalán et al., 2009). both Gondwana and Laurussia margins, which lacks a proper data set to meaningfully constrain vertical axis rotations through time (Fig. 2a). Paleomagnetism is the best tool available to study vertical axis rotations (e.g. van der Boon et al., 2018; Rezaeian et al., 2020) because the Earth's magnetic field is independent of orogen structure (Tauxe, 2010) and therefore rocks magnetized at the same time should show parallel magnetic vectors unless deformation has occurred. Paleomagnetism from SW Iberia is crucial to clarify (1) the relationship between the Cantabrian Orocline and the Central Iberian curve, (2) the formation mechanism of those orogenic curves and (3) their role within the frame of Pangea's amalgamation. Our results confirm the Greater Cantabrian Orocline hypothesis, which buckled the continental margins of both Gondwana and Laurussia during the latest stages of Pangea's formation.

\section{Geological setting}

The Silurian collisions between Laurentia, Baltica and Avalonia (s.1.) formed Laurussia (e.g. Mac Niocaill, 2000; Domeier, 2016). From the late Devonian onward, Laurussia, Gondwana, Siberia, and some smaller lithospheric plates amalgamated to form the supercontinent Pangea (e.g. Nance et al., 2010). One of the most striking relics of Pangea's formation is the westward younging Variscan-Alleghanian orogen, the result of the final collision between Gondwana and Laurussia, which extends from Western-Central Europe and northwest Africa to southeastern North America (Fig. 1). The collision began in the late Devonian times in eastern Europe and continued until Permian times towards southern North America. Orogen formation in the North American sector commenced as late as $\sim 325 \mathrm{Ma}$, coeval with the orogenic collapse of the European sector (e.g. Faure et al., 2009; Hatcher, 2010; Martínez-Catalán et al., 2014). The Variscan-Alleghanian orogenic belt shows a variable trend with a succession of orogenic curves with different origins (cf. Fig. 1): The Bohemian curve (e.g. Tait et al., 1996), the coupled Cantabrian Orocline (e.g. Gutíerrez-Alonso et al., 2012) and Central Iberian curve (e.g. Aerden, 2004), and the Atlantic Canada (e.g. O'Brien and van der Pluijm, 2012), Pennsylvanian, and Alabama curves (e.g. Thomas, 1977).

\subsection{The Variscan belt in Iberia}

The Iberian massif contains an almost continuous cross section of the Variscan orogen (Fig. 2a; e.g. Julivert et al., 1974; Ribeiro et al., 2007). Geographically, the external zones of the Gondwana margin are nestled at the core of the Cantabrian Orocline, to the north, and the hinterland zones are to the peninsula's west to southwest, including the 'Central Iberian Zone' and 'Ossa-Morena Zone', both classical tectonostratigraphic zones in Iberia (Fig. 2; e.g. Diez-Balda, 1995; Azor et al., 2019). Finally, southwestern-most Iberia contains a putative reworked suture of the Rheic ocean, the Pulo-de-Lobo and Beja-Acebuches units; and the South Portuguese Zone, a piece of the fold-and thrust belt from the Laurussian margin (Fig. 2a; e.g. Pereira et al., 2017; Oliveira et al., 2019a).

The Variscan orogen in Iberia shows multiple deformation, metamorphic and magmatic events which in SW Iberia are characterized by a pervasive sinistral component of deformation (e.g. Martínez-Catalán et al., 2014; Azor et al., 2019):

(1) An initial continent-continent collision featuring high pressure metamorphism began ca. 370-365 Ma in Gondwana's authochton (e.g. Quesada and Dallmeyer, 1994; Moita el al., 2005; Rosas et al., 2008; López-Carmona et al., 2014).

(2) Between $360 \mathrm{Ma}$ and $330 \mathrm{Ma}$, a multiphase shortening phase occurred (frequently referred to as D1), accompanied by Barrovian type metamorphism (e.g. Dias da Silva et al., 2020) and plutonism at $\sim 340$ Ma (e.g. Gutiérrez-Alonso et al., 2018). In SW Iberia D1 formed NE-vergent recumbent folds in the southernmost Central Iberian Zone and SW-vergent folds and thrusts in the Ossa 


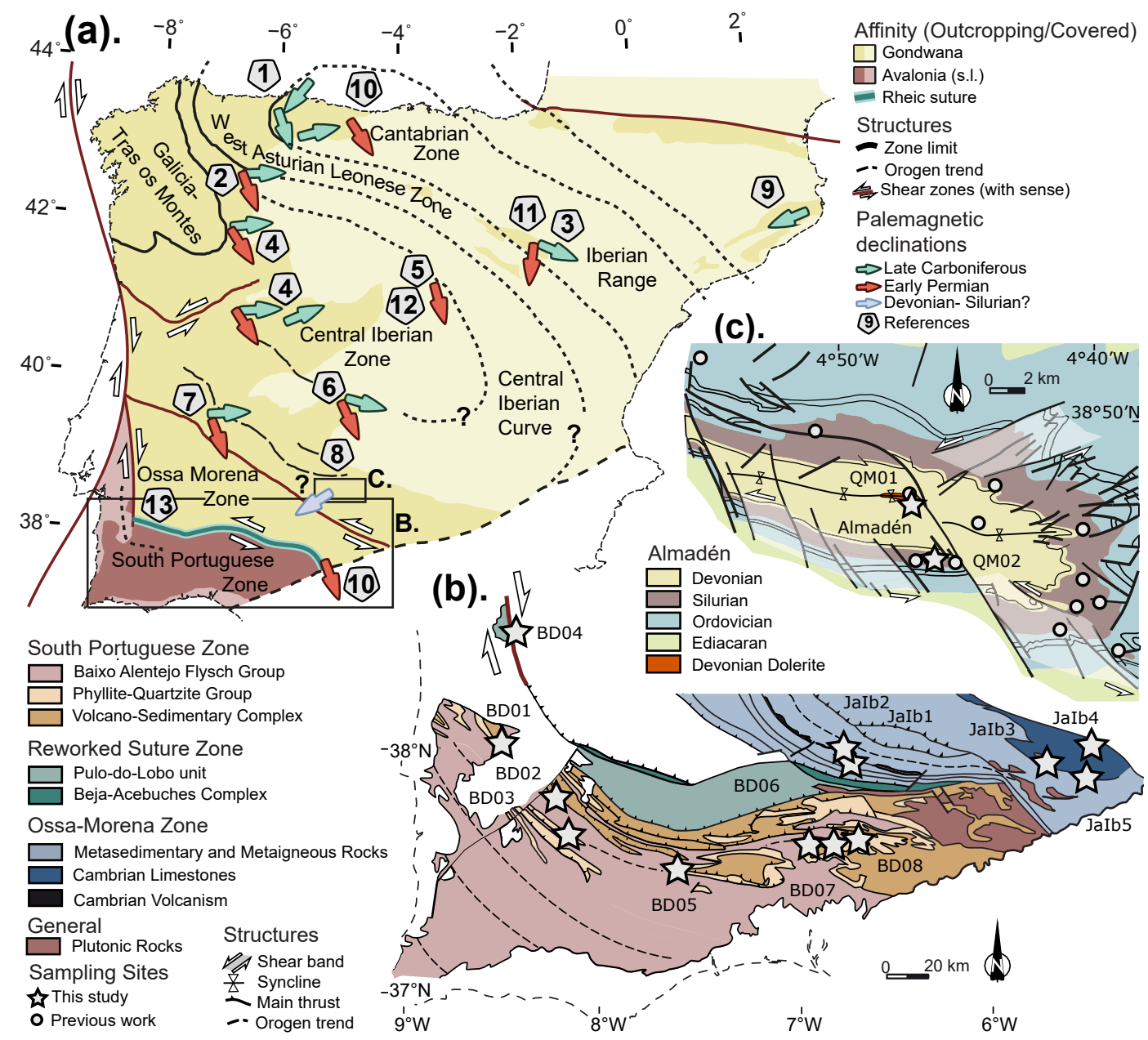

Fig. 2. (a) Variscan zonation in Iberia and available paleomagnetic data from the Permo-Carboniferous. (1) Weil et al. (2013 and references therein); (2) Fernández-lozano et al. (2016); (3) Pastor-Galán et al. (2018); (4) Pastor-Galán et al. (2016); (5) Osete et al. (1997); (6) Pastor-Galán et al. (2015b); (7) Pastor-Galán et al. (2017a); (8) Perroud et al. (1991) and Parés and van der Voo (1992); (9) Edel et al. (2014); (10) Weil et al. (2010); (11) Calvín et al. (2014); (12) van der Voo (1969); (13) Perroud et al. (1985). (b) Simplified structural map of the South Portuguese and Ossa-Morena zones with sampling sites of the present study (open stars). Depicted the Santa Susana Shear Zone, near site BD04. (c) Geological map of the Almadén syncline (Central Iberian Zone) with our sampling sites (open stars) and those of Perroud et al. (1991) and Parés and van der Voo (1992), indicated with open circles.

Morena Zone (e.g. Azor et al., 2019). D1 continued in SW Iberia with an early Carboniferous transtensional event: the continental lithosphere underwent variable extension (e.g. Pérez-Cáceres et al., 2015), with the development of marine basins (Oliveira et al., 2019a) and occurrence of widespread sinistral shearing (e.g. Azor et al., 2019). Coevally, an important extension-related magmatic event happened (Dias da Silva et al., 2018), perhaps assisted by a plume-type magmatism (Simancas et al., 2005) or a slab break-off (Pin et al., 2008).

(3) An extensional collapse, so-called D2, occurred at $\sim 330-318 \mathrm{Ma}$, which formed core-complexes and granitic domes (e.g. Díez Fernández and Pereira, 2016; Rubio Pascual et al., 2016; Dias da Silva et al., 2018; López-Moro et al., 2018; Pereira et al., 2018a, 2018b). The orogenic collapse in the hinterland is coeval and genetically linked to the formation of foreland fold-and-thrust-belts (e.g. Pastor-Galán et al., 2009; Oliveira et al., 2019b; Pereira et al., 2020). In SW Iberia, D2 is characterized by left-lateral transpression forming major shear bands to the north and south of the Ossa Morena Zone (Fig. 2b) and generalized sinistral displacements all along Ossa Morena and South Portuguese Zones. Pérez-Cáceres et al. (2016) estimated over $1000 \mathrm{~km}$ of collisional convergence in SW Iberia, most of it corresponding to left-lateral displacements parallel to the zone boundaries.
(4) A final shortening event (D3) occurred ca. 315-290 Ma, associated with the formation of the Cantabrian Orocline and accompanied by the ubiquitous intrusion of mantle-derived granitoids (e.g. Pastor-Galán et al., 2012a). In SW Iberia D3 is accompanied by left-lateral transpression that continued until at least $310 \mathrm{Ma}$ and perhaps later (Pérez-Cáceres et al., 2015).

\subsection{Curvature in the Iberian Variscides}

The Cantabrian Orocline extends from Brittany following a near $180^{\circ}$ change in strike through the Bay of Biscay, into the NW Iberian Peninsula. There, it allegedly turns back with an opposite sense curvature known as the Central Iberian curve (Figs. 1 and 2a). The Cantabrian Orocline is one of the most studied oroclines in the world (e.g. Gutiérrez-Alonso, 1996; Merino-Tomé et al., 2009; Pastor-Galán et al., 2012b; Murphy et al., 2016; Shaw and Johnston, 2016). Kinematically it has been constrained as a secondary orocline based on extensive paleomagnetic studies (e.g. Hirt et al., 1993; Weil et al., 2013), structural analysis (e.g. Weil et al., 2013; Pastor-Galán et al., 2014) and geochronological investigations (e.g. Gutiérrez-Alonso et al., 2011, 2015). The Cantabrian Orocline buckled a linear portion of the Variscan orogen around a vertical axis between ca. 315-290 Ma, during the D3 deformation phase (e.g. Pastor-Galán et al., 2011; Fernández-Lozano et al., 2019). 

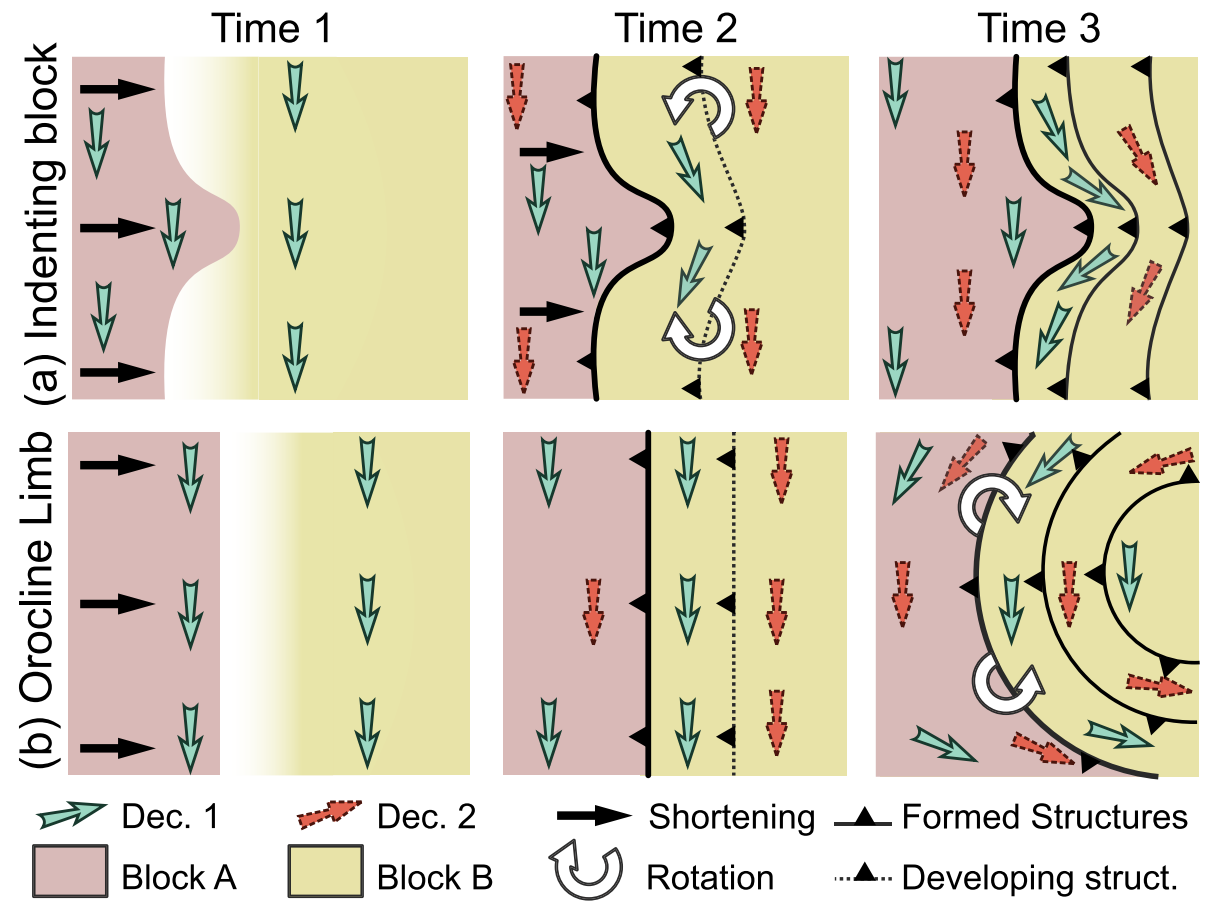

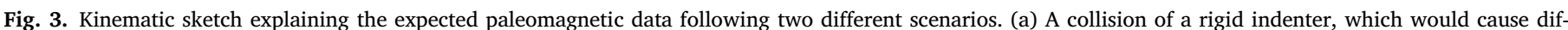

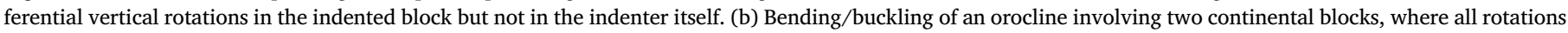
have the same magnitude and are coeval.

Paleomagnetic data from Ireland (Pastor-Galán et al., 2015a) show coeval clockwise rotations of similar magnitude as in the northern limb of the Cantabrian Orocline supporting the Greater Cantabrian Orocline hypothesis, in which orocline formation may have involved both Gondwana and Laurussia accreted continental margins.

In contrast, the geometry and kinematics of the Central Iberian curve, are poorly known (e.g. Staub, 1927; Aerden, 2004; Figs. 1 and 2). The curvature is most obvious at the boundary between the Galicia-Tràs-os-Montes and Central Iberian Zones and to the SE of the Central Iberian Zone (Fig. 2a; Martínez-Catalán, 2012). However, the extent and magnitude of the curvature is under debate with three competing proposals by: (i) Aerden (2004) who envisages a inhomogenous orocline with more curvature in their outer arc than in the inner arc; (ii) Martínez-Catalán (2012) suggesting a $\sim 110^{\circ}$ curvature: and (iii) Shaw et al. (2012) proposing a $180^{\circ}$ curved mountain belt.

The available late Carboniferous kinematic data from central Iberia do not allow for a coeval formation of both the Cantabrian and Central Iberian curvatures (Fig. 2a; e.g. Pastor-Galán et al., 2015b; Dias et al., 2016; Jacques et al., 2018a). Late Carboniferous paleomagnetic data show no differential rotations between the limbs of the Central Iberian curve and the generally determined CCW rotations, which are compatible with the Cantabrian Orocline formation (e.g. Pastor-Galán et al., 2016, 2018) (Fig. 2a). Structurally, D3 deformation patterns around the Galicia-Trás-os-Montes Zone do not support differential vertical axis rotations during the late Carboniferous (Dias da Silva et al., 2017, 2020; Jacques et al., 2018b; Pastor-Galán et al., 2019) only allowing a pre-320 Ma formation for the Central Iberian curve (Pastor-Galán et al., 2016).

A plethora of mechanisms have been suggested to explain the formation of the Cantabrian Orocline since the 1970's (reviewed in Weil et al., 2013, 2019). The only mechanisms proposed so far that can explain the secondary nature of the Cantabrian Orocline and perhaps the Central Iberian curvature are: (1) the indentation of Laurussia in SW Iberia (Fig. 3a; e.g. Lorenz and Nicholls, 1984; Simancas et al., 2005) and (2) a change in the prevailing stress field during the late Carboniferous in relation with the amalgamation of Pangea (Fig. 3b; e.g. Ries and Shackleton, 1976; Gutiérrez-Alonso et al., 2004). The indenter model suggests that a promontory with Avalonian affinity, the South Portuguese Zone (Pérez-Cáceres et al., 2017), collided into Gondwana during the Carboniferous (Fig. 3a). The Laurussian indenter hypothesis is grounded in the present day geometry of the preserved Laurussian affinity outcrops in SW Iberia and NW Africa (Fig. 1). The indenter would nucleate the Central Iberian curve first and later the Cantabrian Orocline (Simancas et al., 2013). The stress-change model postulates that during the late Carboniferous the stress field flipped from orogen perpendicular to orogen parallel shortening (e.g. Merino-Tomé et al., 2009; Murphy et al., 2016; Fig. 3b). Possible mechanisms that could produce such a stress change include a diachronic closure of the Rheic ocean (Pastor-Galán et al., 2015b), self-subduction of Pangea in the Paleotethyan realm (Gutiérrez-Alonso et al., 2008a), a Pangea B to Pangea A transition mega-shear (Martínez-Catalán, 2011; Martínez-García, 2013) or subduction roll-back of the Paleotethys (Pereira et al., 2015).

\subsection{Concise overview of SW Iberian geology}

The South Portuguese Zone comprises the Laurussian foreland foldand-thrust belt in the Iberian Variscides (e.g. Pérez-Cáceres et al., 2017; Pereira et al., 2020). It has a curved shape that roughly follows the trend of the Cantabrian Orocline with a varying strike from $\sim 160^{\circ}$ (NW sector) to $\sim 90^{\circ}$ (eastern side; Fig. $2 \mathrm{~b}$ ). This zone shows little internal deformation and metamorphism, which increases northwards, towards the suture (Onézime et al., 2002; Pérez-Cáceres et al., 2016; Azor et al., 2019). It is constituted of two main units: (1) the Baixo Alentejo Flysch Group at the southwest, which is a composite turbiditic sequence spanning from $330 \mathrm{Ma}$ to $310 \mathrm{Ma}$ (Oliveira et al., 2019b) and (2) the Iberian Pyrite Belt (e.g. Oliveira et al., 2019a, 2019b), a world class volcanogenic massive sulfide deposit that consists of two members (top to bottom): (i) the Volcano-Sedimentary Complex ( $\sim 360 \mathrm{Ma}$ to $\sim 330 \mathrm{Ma})$ is a detrital flysch sequence with bimodal volcanism and the (ii) the Phyllite and Quartzite formation $(\sim 390 \mathrm{Ma}$ to $\sim 360 \mathrm{Ma})$.

The boundary between the South Portuguese and Ossa Morena zones (Fig. 2) includes the Pulo de Lobo unit, a sinistral shear zone (Southern Iberian Shear Zone; Crespo-Blanc and Orozco, 1988) that contains a 
strongly deformed amphibolitic belt with oceanic affinity (i.e. Beja-Acebuches unit; Munhá et al., 1986; Munhá et al., 1989; Quesada and Dallmeyer, 1994; Quesada et al., 2019) and the dextral D3 Santa Susana Shear Zone (Oliveira et al., 2007). The Pulo de Lobo Unit is a low grade metamorphic accretionary prism with clastic sedimentary rocks and basalts with MORB signature. The accretionary prism formed at the Avalonian margin during the late Devonian (ca. 375-360 Ma) according to the available palynological data, a process that may have lasted until the early Carboniferous (Pereira et al., 2018a, 2018b, 2019). This accretionay prism, together with the oceanic-derived Beja-Acebuches unit, indicates a suture, usually interpreted as the Rheic ocean or a subsidiary basin (e.g. Azor et al., 2019). Whether the Pulo de Lobo is a separate tectonostratigraphic Zone is under debate (Pereira et al., 2017).

The Beja-Acebuches complex and other associated oceanic rocks show a protracted history of ocean opening, closure, and reopening (e.g. Quesada et al., 2019). The complex contains rocks suspected to have formed during early Paleozoic times, which would represent the Rheic ocean (Quesada et al., 2019). The majority of gabbro and amphibolitic rocks formed $\sim 340 \mathrm{Ma}$ (Azor et al., 2008) and possibly represent relics of a subsidiary seaway, which opened during the Variscan transtension event in SW Iberia (e.g. Pérez-Cáceres et al., 2015; Quesada et al., 2019). To the west, this oceanic-like transtensional rock sequence is represented by nearly undeformed volcano-sedimentary basins (Toca da Moura and Cabrela basins, $\sim 340 \mathrm{Ma}$ ), which overlies the high-grade metamorphic units of the Ossa-Morena Zone (Pereira et al., 2012a,b; Oliveira et al., 2019a). The Ossa-Morena Zone lies to the north of the suture and represents a distal platform of the Gondwanan margin (e.g. Pereira et al., 2012a,b; Arenas et al., 2016). It comprises an Ediacaran continental arc and lower Paleozoic volcanic and sedimentary sequences deposited during an intracontinental rift to passive margin transition (Quesada, 1996; Eguíluz et al., 2000; Sánchez-García et al., 2019). The Ediacaran arc contains volcanic, plutonic and shallow marine sedimentary rocks (e.g. Eguíluz et al., 2000; Sánchez-Lorda et al., 2016). Overlying the Ediacaran arc, a rift-to-drift Cambrian to middle Ordovician sequence crops out with lower Cambrian rift magmatism, iron-rich carbonates and volcano-sedimentary rocks (Liñán and Quesada, 1990; Sánchez-García et al., 2003, 2010; Linnemann et al., 2008; Pereira et al., 2012a,b). Conformably over the rift-to-drift sequence, a $\sim 7000 \mathrm{~m}$ thick series of mid-Ordovician to mid-Devonian passive margin siliciclastics with Gondwana affinity occurs (Robardet and Doré, 1988; Gutiérrez-Marco et al., 2019), putatively followed by syn-orogenic Carboniferous turbidites (Sánchez-García et al., 2003). Structurally, the Ossa-Morena Zone behaves as a large-scale sinistral strike-slip duplex, that formed during the early stages of the orogeny, and reactivated during later stages (e.g. Quesada and Dallmeyer, 1994). During the Variscan orogeny, the Ossa Morena Zone underwent varying metamorphic conditions, mostly greenschist facies but also including some high grade metamorphic regions (Pereira et al., 2012a,b; Dias da Silva et al., 2018).

The Central Iberian Zone extends from the northwesternmost part of Iberia to the southwestern sector. In the SW, the boundary with the Ossa Morena Zone is a sinistral shear zone (known as the Tomar-BadajozCordoba Shear Zone (e.g. Linnemann et al., 2008) (Fig. 2a). Central Iberian Zone's stratigraphy starts with an Ediacaran to lower Cambrian forearc turbiditic sequence, overlain by a Paleozoic passive margin sequence, spanning from Cambrian to Devonian times (Valladares et al., 2000; Gutiérrez-Marco et al., 2019; Pastor-Galán et al., 2020). Occurrences of Siluro-Devonian volcanic rocks are common (e.g. Gutiérrez-Alonso et al., 2008b), particularly in the Almadén syncline, near its boundary with the Ossa-Morena Zone. During the Variscan orogeny, the Central Iberian Zone underwent the earlier described deformation phases: D1 with Barrovian metamorphism, D2 with localized Buchan metamorphism in gneiss domes and D3 with only little to no metamorphism (e.g. Diez-Balda, 1995; Dias da Silva et al., 2020).

The Almadén syncline (in SE Central Iberian Zone) is a $30 \mathrm{~km}$ long and $15 \mathrm{~km}$ wide syncline with a $\sim 100^{\circ}$ striking Variscan fold (Fig. 2C; e.g. Aller et al., 1986). Its fold axis is horizontal throughout most of the structure but becomes steeply plunging and conical in shape at its eastern periclinal closure (Vergés, 1983). The structure formed during D1 (Vergés, 1983) and underwent left-lateral transcurrency at D3 (Aller et al., 1986). This D3 transcurrency formed fragile-ductile shear bands and locally a rough cleavage (Aller et al., 1986; Palero-Fernández et al., 2014). A large amount of volcanic rocks is intercalated between the marine strata in the syncline's Silurian-Devonian stratigraphy; the structure hosts the largest amount of mercury in the world (Palero-Fernández et al., 2014).

\subsection{Previous paleomagnetism in SW Iberia}

The only previous paleomagnetic study in Ossa Morena and South Portuguese zones (Perroud et al., 1985) focused on the Beja Igneous Complex, which includes a layered gabbroic sequence, dated at ca. 353-345 Ma (Pin et al., 2008). Data shows varied inclinations and declinations in the gabbros and complex overprints elsewhere. The authors did not consider any structural corrections, assuming the gabbro was undeformed. The layered gabbroic sequence shows a magmatic foliation sub-parallel to a conspicuous layering, and often displays Carboniferous weak to moderated ductile deformation (e.g. Jesus et al., 2016 ). The dataset of Perroud et al. (1985) is untrustworthy without knowing which corrections should be applied.

Paleomagnetic data from the northern and central sectors of the Central Iberian Zone show a widespread late Carboniferous remagnetization in sedimentary rocks, a primary magnetization in D2 granites (intruded $\sim 320 \mathrm{Ma}$ ), and significant CCW rotations (Pastor-Galán et al., 2015b, 2016, 2017b; Fernández-lozano et al., 2016) (Fig. 2a). Two previous studies identified a potentially older magnetization in the Almadén syncline (Perroud et al., 1991; Parés and van der Voo, 1992) (Fig. 2a and c). Both previous paleomagnetic studies in the Almadén region, by Perroud et al. (1991; Silurian tuffs and lavas) and Parés and van der Voo (1992; Ordovician lava flows and Devonian dolerites), identified two different magnetization components. The first component, so-called " $\mathrm{I}$ " or "B" (by Perroud et al., 1991; Parés and van der Voo, 1992, respectively), is downwards, single polarity and shallow with declinations towards the E or SE; it demagnetizes up to $500^{\circ} \mathrm{C}$ or $40 \mathrm{mT}$ (Supplementary File 1C). Both studies conclude that this component is a late Carboniferous overprint (post D2). Pastor-Galán et al. (2015b) interpreted the observed CCW rotations as coeval with the formation of the Cantabrian Orocline (syn D3).

The second component, "II" or "C" (Perroud et al., 1991; Parés and van der Voo, 1992 respectively), is also a single polarity component, but points upwards with inclinations of ca. $-35^{\circ}$ and declinations to the NE. This is a high-temperature and high-coercivity component (demagnetizing from $400{ }^{\circ} \mathrm{C}$ to $600{ }^{\circ} \mathrm{C}$ or in the $40-100 \mathrm{mT}$ range). Perroud et al. (1991) interpreted "II" as Silurian, since k (precision parameter) got slightly higher after a correction for the eastern syncline's distinctly plunging axes. We have reservations concerning this procedure since Perroud et al. (1991) applied a single axial plunge correction to all investigated sites, even to those where the axis is sub-horizontal. In addition, the structural data of the Almadén syncline is not robust enough for reconstructing uniquely the kinematics of the fold axis to its present-day plunge. Uncertain corrections in conical folds and/or plunging fold axis often result in spurious rotations, making paleomagnetic directions difficult to interpret (Pueyo et al., 2003, 2016). In addition, Parés and van der Voo (1992) found the same component in Devonian dolerites before applying any correction and they hypothesize an early Carboniferous origin. The meaning of the "II" or "C" component remains puzzling. However, if it was acquired during a normal polarity chron (i.e. with a declination $\sim 250^{\circ}$ ), it would indicate $\sim 90^{\circ} \mathrm{CW}$ rotation in SW Iberia, which, in turn, would support a pre-320 Ma vertical axis rotation of the Central Iberian curve (Fig. 2a). 


\section{Methods and results}

We collected 429 oriented standard cylindrical core samples (diameter $2.5 \mathrm{~cm}$ ) with a petrol-powered drill. In total, we targeted 15 sites with fresh outcrops, in non-metamorphic rocks with little to no internal deformation (Fig. 2a). We retrieved a minimum of 10 cores ( 3 sites) and preferably $>20$ cores per site (11 sites). One site (BD02) was very hard to drill; only 4 cores could be collected. Supplementary Files 1A and 2 contain detailed outcrop descriptions and the outcrop locations, respectively.

We sampled 7 sites in the Volcano-Sedimentary Complex of the Iberian Pyrite Belt, in the South Portuguese Zone. The lithologies of each site are basic lavas and acidic tuffs (BD01, BD03, BD06-BD08), subvolcanic bodies (BD05), and jasperites (BD02), sampled along the varying orogen trend (Fig. 2b). Six sites were sampled in the Ossa Morena Zone (Fig. 2b). We sampled one site (BD04) in a basaltic pillow-lava formation of the Carboniferous syn-Variscan Toca da Moura unit, near the boundary between the South Portuguese and Ossa-Morena zones. The remaining sites are Cambrian rocks located close to Ossa Morena's southern boundary. We sampled Rheic ocean rift related volcanics (JaIb01-02), iron-rich limestones (JaIb04-05) and a gabbroic intrusion (e.g. Cambeses et al., 2018).

The samples collected in the Almadén syncline (SE Central Iberian Zone) constitute the QM series. We cored 90 samples at two sites (Fig. 2c). The first site is QM01 (31 cores), a Devonian dolerite in the core of the syncline which corresponds to site $01 \mathrm{CE}$ from Parés and van der Voo (1992). The second site is QM02 (59 cores), consisting of Silurian tuffs and lavas previously sampled by Perroud et al. (1991, sites AM, AN, $\mathrm{AO}, \mathrm{AX}$ and $\mathrm{AY}$ ). QM01 and QM02 are respectively in the hinge and southern limb of the Almadén syncline in an area with a horizontal fold axis without major structural complications (Fig. 2c).

We performed rock magnetic (Fig. 4), Anisotropy of Magnetic Susceptibility (AMS) (Fig. 5) and paleomagnetic directional analyses (Figs. 6-10) to the sample collection at Paleomagnetic Laboratory 'Fort Hoofddijk', Utrecht University (The Netherlands). We also provide all rock magnetic data in Supplementary Files 3 and 4. The paleomagnetic data and interpretation are given in Supplementary Files 5 and 6 (the .col and.pub files come from paleomagnetism.org; Koymans et al., 2020), which are accessible through the persistent identifier associated with this publication's DOI of paleomagnetism.org.

\subsection{Rock magnetism}

Thermomagnetic and hysteresis loop analyses are useful to identify and understand the magnetic mineralogy and the sample's magnetic history. In addition, the optimal strategies for the stepwise demagnetization of their natural remanent magnetization (NRM) can be selected. We analyzed 19 samples, representative of the various lithologies. Thermomagnetic runs were performed with a modified horizontal translation Curie balance (Mullender et al., 1993), and hysteresis loops using a Micromag AGFM 2900-02 apparatus. Field settings are sample specific, and are detailed in the data files (Fig. 4, Supplementary File 3A and B).

Many samples from the BD series (South Portuguese Zone) show a paramagnetic curve with a prominent drop in the magnetization between $500{ }^{\circ} \mathrm{C}$ and $560{ }^{\circ} \mathrm{C}$, which evidences the presence of (titano-)magnetite with a low but variable degree of titanium substitution. BD01-35 (Fig. 4) shows a sharp drop between 660 and $680{ }^{\circ} \mathrm{C}$ typical of hematite. BD02 (sedimentary jasper, Fig. 4) and BD06-12 (acidic tuffs) show a marked decrease of magnetization from $200{ }^{\circ} \mathrm{C}$ to $400{ }^{\circ} \mathrm{C}$, and a later sharp decrease between $560{ }^{\circ} \mathrm{C}$ and $580{ }^{\circ} \mathrm{C}$. BD06-5 shows a typical paramagnetic curve with alteration at about $400-420{ }^{\circ} \mathrm{C}$ indicating the presence of non-magnetic sulfides (likely pyrite) that first oxidize to magnetite followed by oxidation to hematite (Supplementary File 1B).

The JaIb series (Ossa-Morena Zone, Supplementary File 1B) shows several types of distinct magnetic behavior. JaIb01 (red pillow lavas)

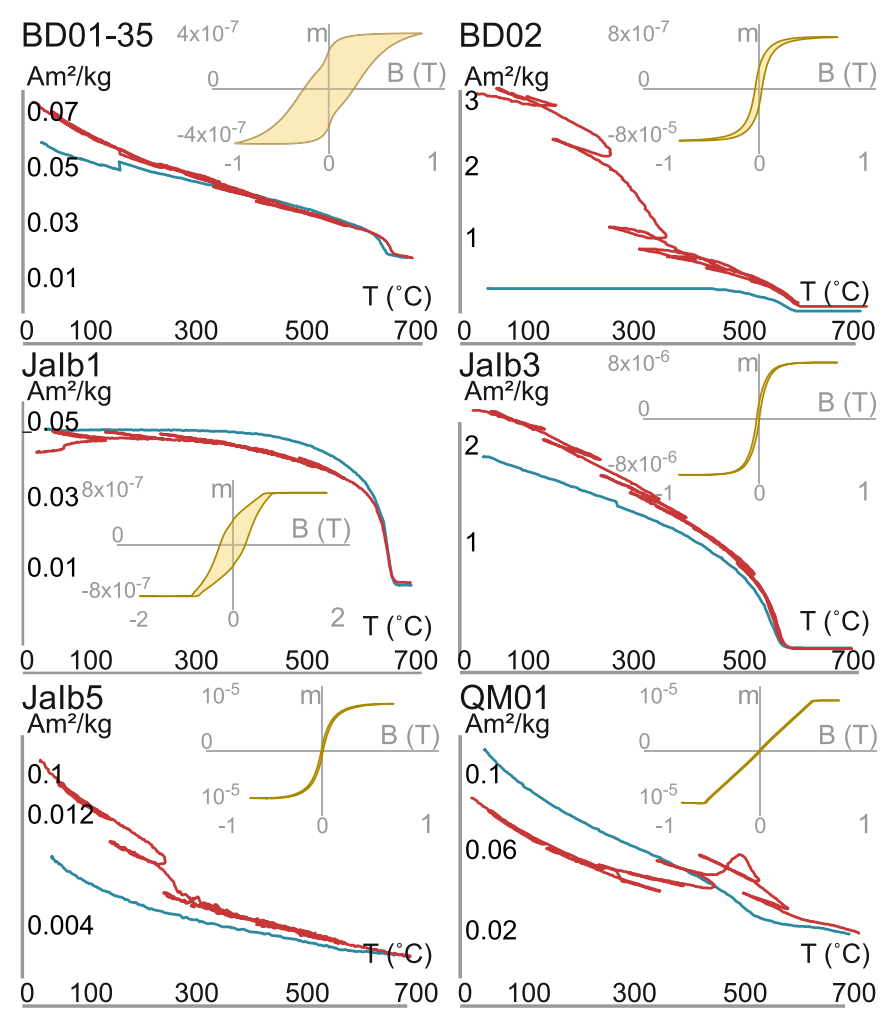

Fig. 4. Representative thermomagnetic curves and hysteresis loops of the different lithologies sampled. Sample BD01-35 (spilites and tuffs) shows a magnetization drop at $580{ }^{\circ} \mathrm{C}$, and hysteresis loop characteristic of hematite. Sample from site BD02 (sedimentary jasper) shows a maghemite thermomagnetic curve with a close to single domain hysteresis loop. Sample from site JaIb1 (wine-colored pillow lavas) shows that the main magnetic carrier is hematite, and an overcorrected hysteresis loop. Sample JaIb3 shows a strong decay in magnetization between $\sim 500$ and $\sim 550{ }^{\circ} \mathrm{C}$ characteristic of magnetite, with a near superparamagnetic hysteresis loop. Sample JaIb5 shows an early decay of magnetization between $\sim 200{ }^{\circ} \mathrm{C}$ and $\sim 300{ }^{\circ} \mathrm{C}$, characteristic of Greigite, with a near superparamagnetic hysteresis loop. Sample from site QM01 (dolerite) shows the presence of pyrite oxidation starting at $420{ }^{\circ} \mathrm{C}$ in the thermomagnetic runs and a failed micromagnetic measurement.

shows a stable magnetization until $625^{\circ} \mathrm{C}$ followed by a sharp decrease up to $700{ }^{\circ} \mathrm{C}$, typical of hematite (Fig. 4). The heating curves of JaIb2 (spilite) and JaIb3 (gabbro, Fig. 4) show slight decay up to $560{ }^{\circ} \mathrm{C}$ followed by a sharp decrease until $580^{\circ} \mathrm{C}$, the classic behavior of magnetite. JaIb4 and JaIb5 (limestones) show a paramagnetic hyperbola with sulfide alteration (likely pyrite) starting slightly over $400{ }^{\circ} \mathrm{C}$ and a minor decay at $\sim 580^{\circ} \mathrm{C}$, indicating some magnetite. A second sample of JaIb05 also shows a curve similar to that of greigite (Fig. 4) (Dekkers et al., 2000).

In the QM series (Almadén, SE Central Iberian Zone, Supplementary File 1B), both QM01 (dolerite) and QM02 (lavas and tuffs) show paramagnetic hyperbolas. QM01 (Fig. 4), shows alteration over $400{ }^{\circ} \mathrm{C}$ indicating the presence of non-magnetic sulfides (pyrite).

The majority of the hysteresis loop results show pseudo-single domain behavior (e.g. Fig. 4, BD02). BD01-35 (Fig. 4) indicates hematite, which concurs with the thermomagnetic analysis of this sample. Some sites (e.g. JaIb3 in Fig. 4) further show a near super-paramagnetic behavior. Some samples show an atypical behavior, which we consider to be failed measurements (e.g. Fig. 4, QM01).

\subsection{Anisotropy of the magnetic susceptibility (AMS)}

AMS is a sensitive, non-destructive method to describe preferred orientations of mineral crystal axes, even in weakly deformed contexts 


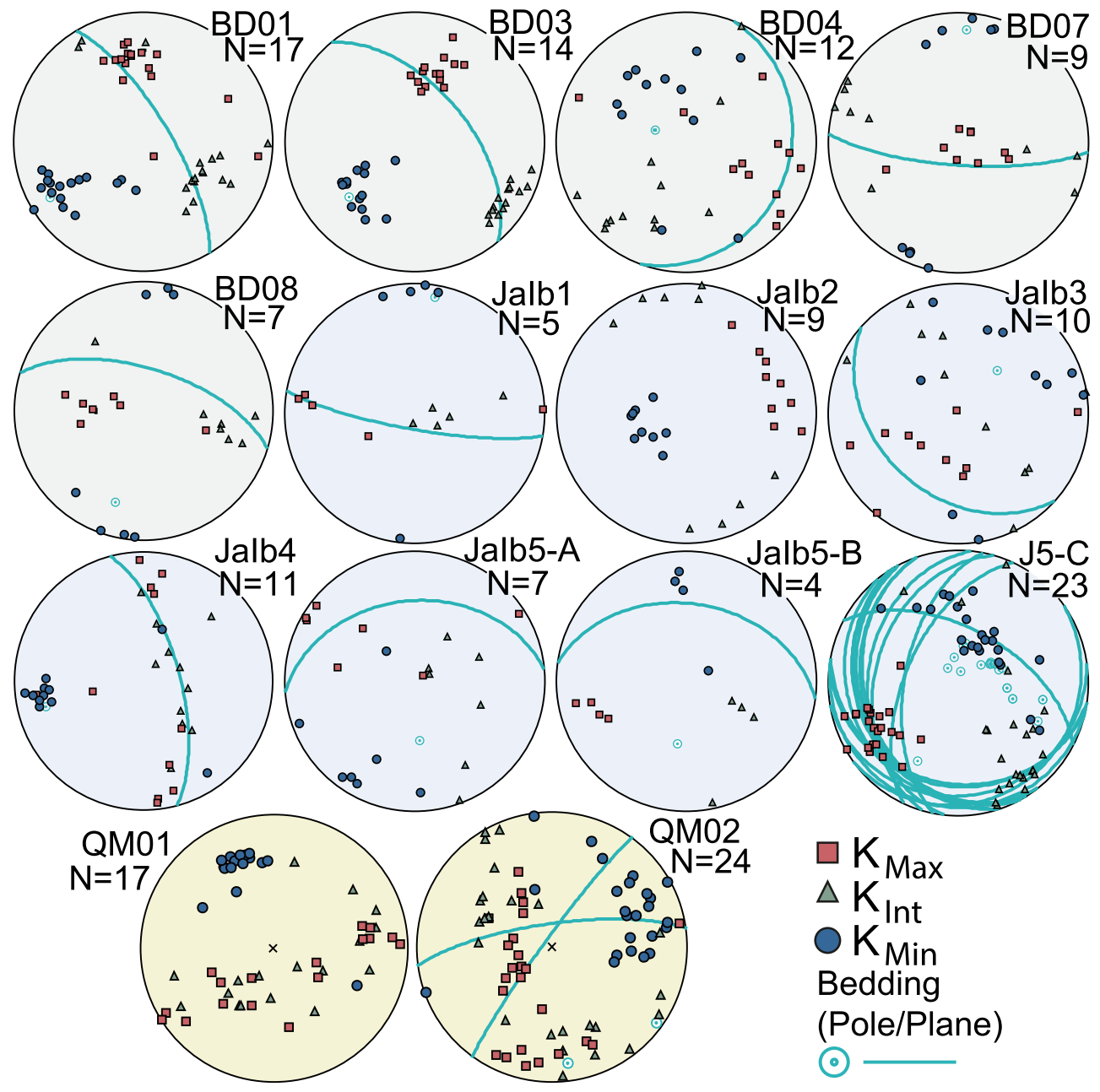

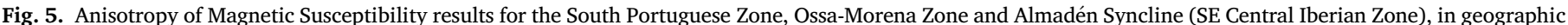
coordinates. See text for details.

(e.g., Borradaile and Jackson, 2004; Parés, 2015). The AMS ellipsoid ( $\mathrm{k}_{\max }$, long axis; $\mathrm{k}_{\text {int }}$, intermediate axis; and $\mathrm{k}_{\min }$, short axis; Fig. 5 ) is a proxy for the deformation ellipse of a sample (Borradaile and Jackson, 2004). We analyzed a total of 169 cores with an AGICO MFK1-FA kappabridge (lowest detectable susceptibility change of $1 \times 10^{-8} \mathrm{SI}$ ). We provide all AMS data files in Supplementary File 4.

In the BD series (South Portuguese Zone), we analyzed sites BD01, 03, 04,07 and 08 (Fig. 5). They show a magnetic susceptibility of $\sim 10^{-4} \mathrm{SI}$ (i.e. expressed per unit volume) and degree of anisotropy $\mathrm{P}\left(\mathrm{k}_{\max } / \mathrm{k}_{\min }\right)<$ 1.12 (i.e. $12 \%$ anisotropy). All sites indicate a general tendency to an oblate shape with the exception of BD04, which shows a quasi random fabric. Sites BD01 and BD03 show $\mathrm{k}_{\text {int }}$ and $\mathrm{k}_{\min }$ in a close to girdle distribution perpendicular to the bedding plane (Fig. 5). In sites BD07 and $\mathrm{BD} 08, \mathrm{k}_{\max }$ and $\mathrm{k}_{\min }$ elongate towards each other, along a non-bedding plane (Fig. 5).

We analyzed all samples from the JaIb series (Ossa-Morena Zone). Sites JaIb1 (susceptibility $10^{-4}$ SI, $\left.\mathrm{P}=1.3\right)$ and JaIb2 $\left(\sim 10^{-3} \mathrm{SI}, \mathrm{P}=\right.$ 1.14) show an oblate ellipsoid, in the case of JaIb1 with $\mathrm{k}_{\min }$ perpendicular to the bedding plane (Fig. 5). Site JaIb3 (gabbro) does not present a clear grouping of the anisotropy axes. Site JaIb4 (limestone) shows oblate ellipsoids but with a low anisotropy level with its short axis perpendicular to bedding (Fig. 5). Site JaIb5 results are varied with both oblate and prolate ellipsoids and $\mathrm{P}$ values around 1.1. $\mathrm{k}_{\max }$ orientations coincide with the measured fold axis, $\mathrm{k}_{\min }$ approximately coincides with the pole to bedding although it seems to follow a great circle with $\mathrm{k}_{\mathrm{int}}$, perpendicular to the fold axis.
In the QM series (Almadén, SE Central Iberian Zone), site QM01 (dolerite) shows low anisotropy in all samples (susceptibility $10^{-4}$ SI; P $<1.012$ ) and oblate shape. The tuffs and lavas of site QM02 show slightly higher anisotropy (susceptibility varies from $10^{-4}$ to $10^{-3} ; 1.02<\mathrm{P}<$ 1.1) with $\mathrm{k}_{\min }$ loosely clustered, but not parallel to the bedding pole. $\mathrm{k}_{\max }$ and $\mathrm{k}_{\mathrm{int}}$ are dispersed indistinguishable in a great circle, similar to site QM01.

\subsection{Paleomagnetism}

We obtained paleomagnetic directions with two 2G-SQUID magnetometers for both alternating field (AF) and thermal demagnetization. Thermal demagnetization was performed in $20-50{ }^{\circ} \mathrm{C}$ steps from room temperature to complete demagnetization (Fig. 6). AF demagnetization was performed with a robotized magnetometer (Mullender et al., 2016) with 18 steps with variable field increments (4-10 mT) up to $100 \mathrm{mT}$. We pre-heated our limestone samples up to $150{ }^{\circ} \mathrm{C}$ prior to $\mathrm{AF}$ demagnetization to remove the effect of a possible superficially oxidized rim of the magnetite grains (van Velzen and Zijderveld, 1995). Principal component analysis (Kirschvink, 1980) was used to calculate magnetic component directions from "Zijderveld" diagrams (Zijderveld, 1967) using Paleomagnetism.org (Koymans et al., 2016, 2020) (Fig. 6). We applied a fixed $45^{\circ}$ cut-off to the VGP distributions of each site and used the Deenen et al. (2011) criteria to evaluate the scatter of VGPs (cf. Figs. 8-10). In samples where the NRM components are not fully resolved but follow a great circle path, we fitted a great circle instead. In such sites, 


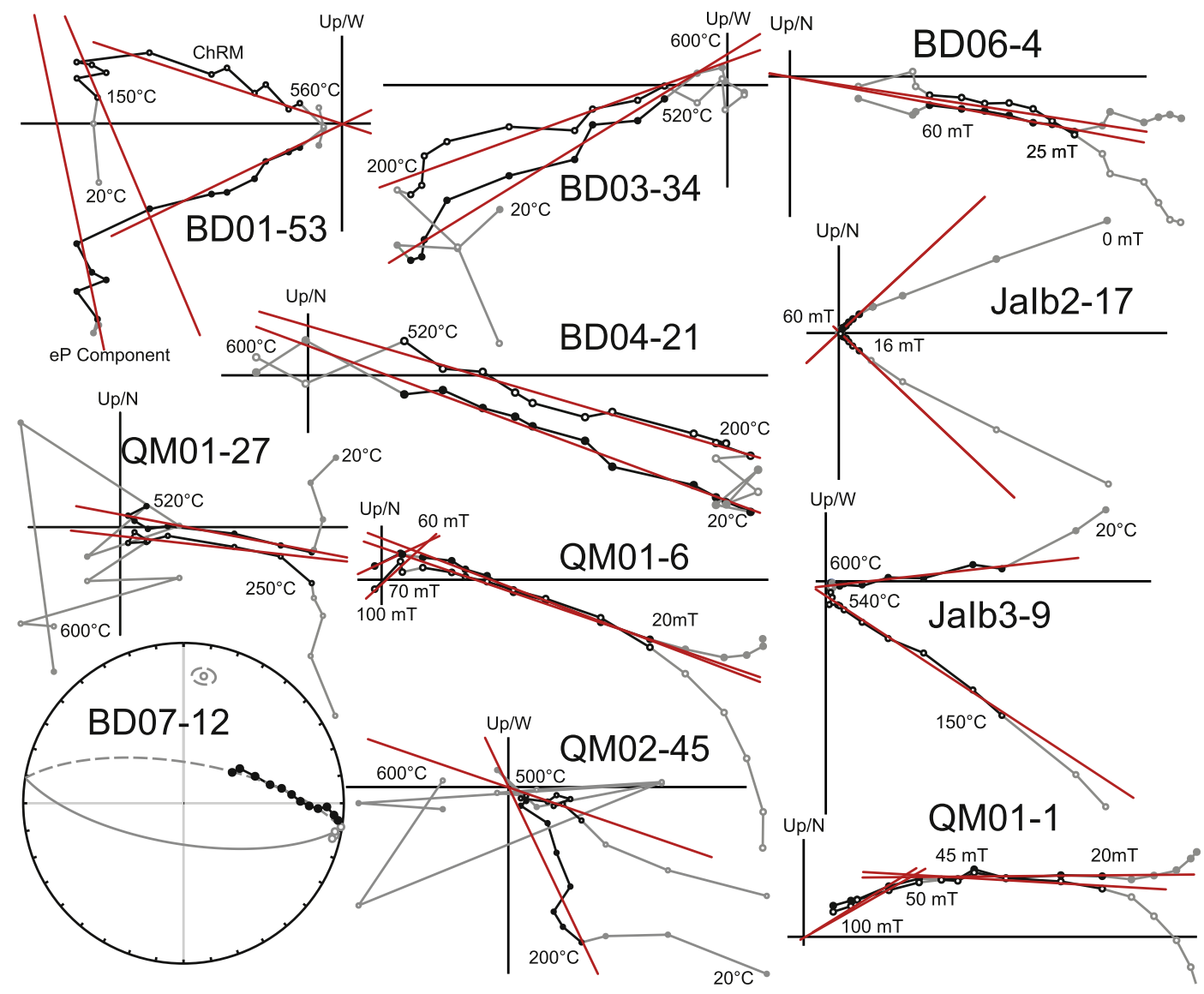

Fig. 6. "Zijderveld" diagrams and great circle fitting in geographic coordinates. Solid points represent projection in the horizontal plane, open points the vertical plane. Raw data are in Supplementary File 4.

we first identified any reliable component to subsequently fit great circle solutions (Fig. 6) following the McFadden and McElhinny (1987) approach, combining great circles and linear best fits (Figs. 6-10). We analyzed the very low temperature/coercivity overprints in all sites and areas to scrutinize their origin. In most sites (only exceptions JaIb1, JaIb4 and JaIb5), this low temperature $\left(20-200{ }^{\circ} \mathrm{C}\right)$ and/or low coercivity $(0-16 \mathrm{mT})$ overprint has the same direction as the present-day Earth's magnetic field, and we named that component PD (Supplementary File 1C).

A recurring component is found in 7 sites of the $\mathrm{BD}$ and JaIb series. This component shows a reversed single polarity with very shallow inclinations and declinations towards the SSE. It demagnetizes between typically $240-560{ }^{\circ} \mathrm{C}$ or $16-70 \mathrm{mT}$ steps (thermal and AF respectively) with variable Maximum Deviation Angles (MAD, generally not anchored to the origin), but always $<15^{\circ}$. It clusters better before any tilt correction and its statistical values are $n=62$ (number of samples); dec/ inc $=160.6^{\circ} / 1.6^{\circ}$ (declination/inclination); $\mathrm{k}=23.6$ (concentration parameter on directions), $\alpha_{95}=2.9^{\circ}$ (Fisherian uncertainty of the average direction); $\mathrm{K}=31.3$ (concentration parameter on virtual geomagnetic poles - VGP), A95 $=2.5^{\circ}$ (uncertainty on VGP) (Fig. 7 , Table 1, Supplementary File 1C). Due to its consistency throughout these sites and post-tilting character we have averaged all specimens (62) where we found this component. It shares a common true mean direction (Tauxe, 2010; Koymans et al., 2016) with the primary magnetization found in the neighboring El Viar Permian basin (Weil et al., 2010; named eP by them (for early Permian); cf. Fig. 7c of this contribution). Hereafter, we refer in our study to this component as eP.

The BD series shows a shallow (inclination between $\sim 20^{\circ}$ and $-1^{\circ}$, Table 1), single polarity component with a varying $\mathrm{E}$ to SE trend (between $95^{\circ}$ and $125^{\circ}$; Fig. 8 , Table 1). It unblocks from $240{ }^{\circ} \mathrm{C} / 16 \mathrm{mT}$ to full demagnetization. In some samples, this component occurs together with the eP component. When they occur together, the samples often contain a composite direction that follows a great circle (especially in BD07, Fig. 8).

In general terms, this component clusters better between sites before any tilt correction, however, sites BD03 and BD04 cluster better after full tilt correction (Fig. $8 \mathrm{~g}$ and h). VGP distributions of this component are circular in all sites, except for BD07, all passing the Deenen criteria (Deenen et al., 2011) with concentration parameter (k) between 16.4 and 74 (Fig. 8, Table 1). Since this component is not uniformly rotated with respect to $\mathrm{eP}$, but shows the same polarity and inclination range, we have named it " $R$ " component (for Rotated). This component does not occur in site BD08 which shows only the eP component, and in site BD02 whose 4 cores show a non-compatible average to ' $R$ ' $\left(\mathrm{dec} / \mathrm{inc}=13.8^{\circ} / 33.79^{\circ}\right.$; Fig. 8 and Table 1).

The JaIb series show variable directions and results. Site JaIb1 shows a very elongated distribution that follows a great circle from present-day field to a direction that was impossible to isolate reliably, but which would be compatible with the R or eP components (Fig. 9). Since we could not successfully isolate a direction from the distribution, we do not consider this site further. Site JaIb2 shows a shallow inclination, single polarity component with declinations to the $\mathrm{E}$ that we consider the same as the R component in the BD series (Fig. 9 and Table 1). In site JaIb3 we could isolate both a present day (PD) component and an eP component.

In site JaIb4 we could only retrieve a poorly clustered distribution in the SW quadrant of a stereonet. Although the $45^{\circ}$ cut-off improves the clustering, it removes points that are visually part of the distribution. Inclinations and declinations vary substantially, from very shallow to very steep but always downward (Fig. 9 and Table 1). Finally, in site JaIb5 we could identify a present day overprint (PD), as well as a set of 

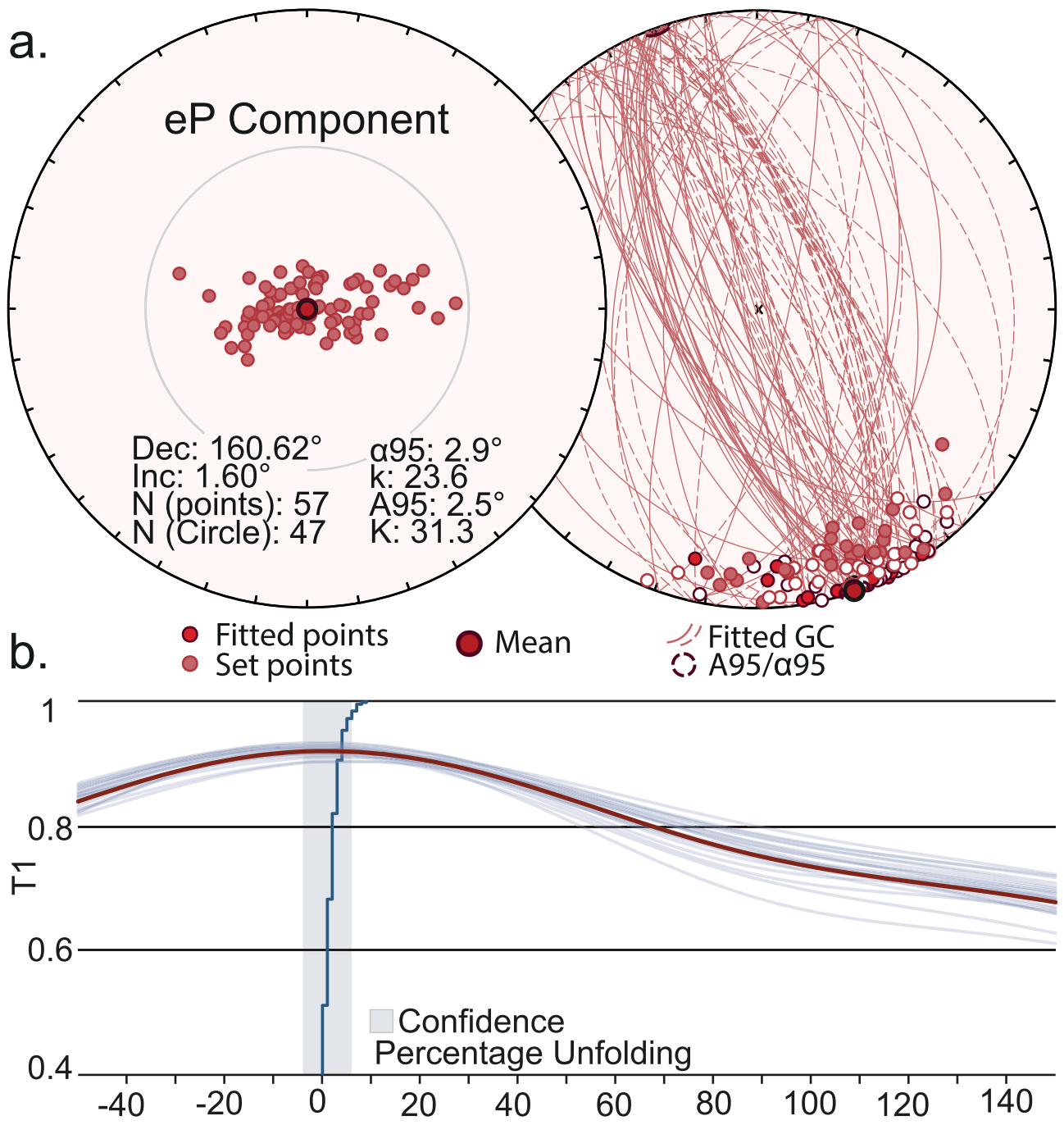

C.

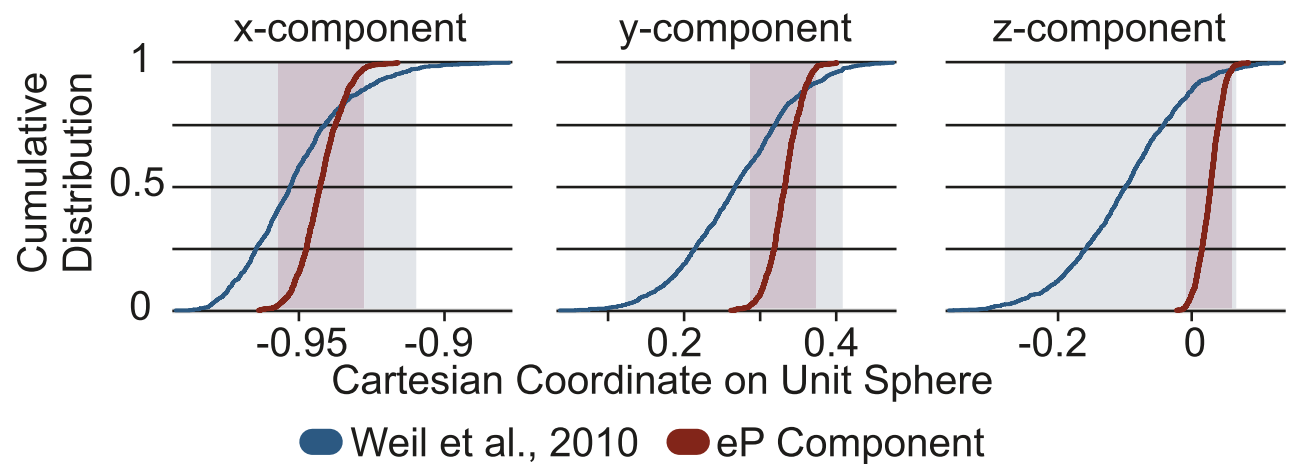

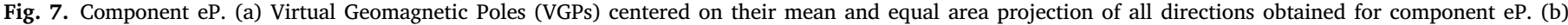

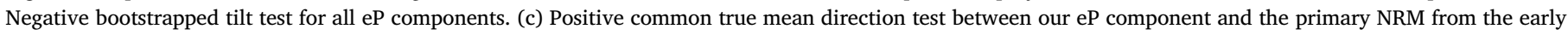
Permian El Viar Basin (Weil et al., 2010).

very scattered directions with a $\mathrm{k}=2.62$ before the $45^{\circ}$ cut-off, which implies a quasi-random distribution. The cut-off improves the concentration parameter $(\mathrm{k}=8.26)$, but only after rejecting 25 samples out of 44 ( $57 \%$ of the samples). We separated the directions in site JaIb5 based on their magnetic mineralogy. A set of samples unblocks between $100{ }^{\circ} \mathrm{C}$ and $380^{\circ} \mathrm{C}$ with little to no decay in $\mathrm{AF}$, implying that pyrrhotite is the magnetic component. We call this set of directions Py component (for Pyrrhotite, the suspected carrier). The concentration parameter of the Py component without any cut-off is very low $(\mathrm{k}=3.61)$ implying scattered directions. The distribution again becomes tighter after application of the cut-off, which discards $50 \%$ of the samples (10 out of 20 ). The average parameters after the cut-off are dec/inc $=153.11^{\circ} / 68.81^{\circ}, \mathrm{k}=19.87$ (Fig. 9 and Table 1). The rest of the samples show directions that unblock between $200{ }^{\circ} \mathrm{C}$ and $580{ }^{\circ} \mathrm{C}$ or from $12 \mathrm{mT}$ to $60 \mathrm{mT}$, likely indicating magnetite as a carrier. We call this component $\mathrm{M}$ for magnetite. This set of directions is also poorly clustered $(\mathrm{k}=2.52)$ before any cut-off. The 


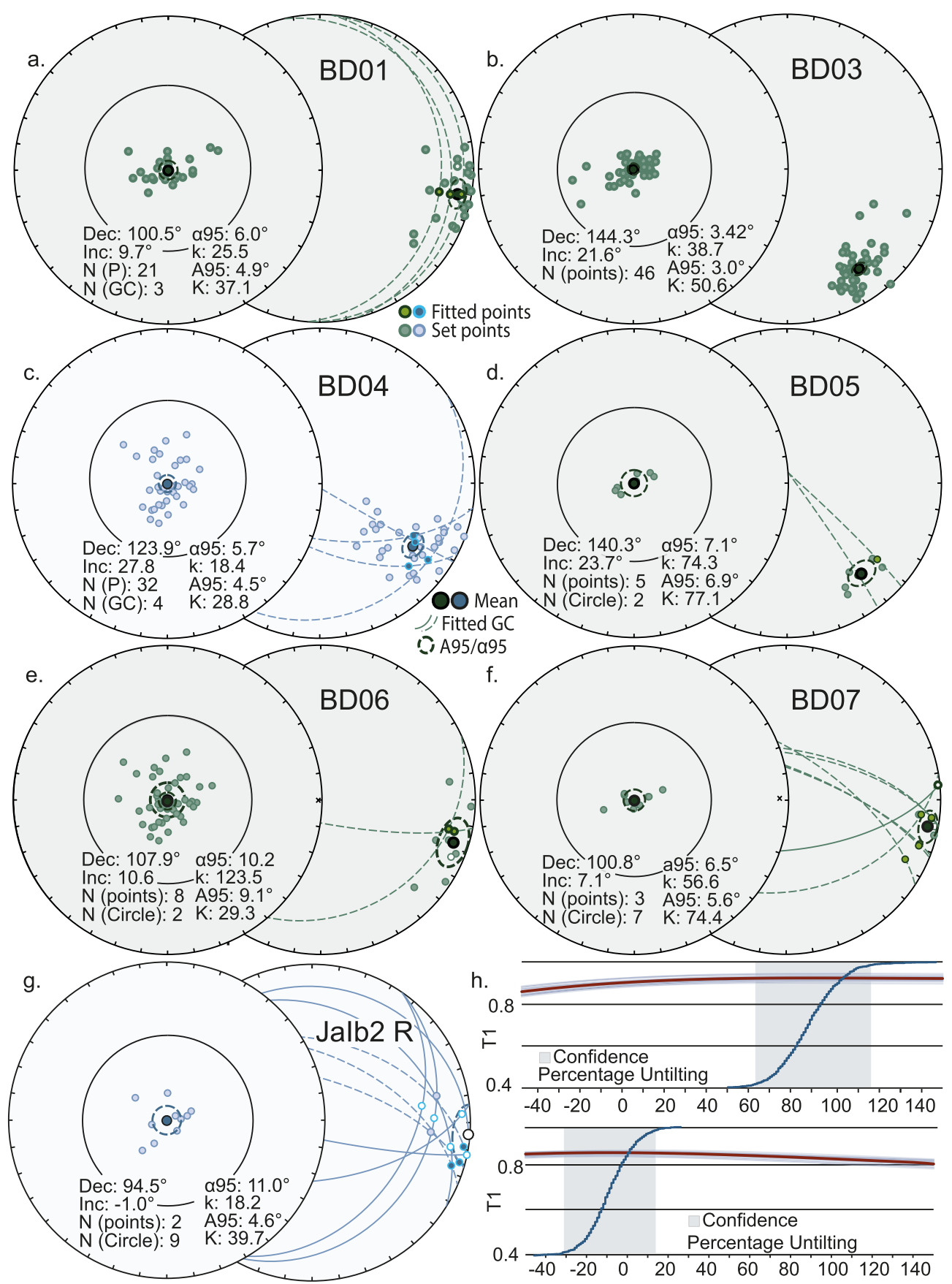

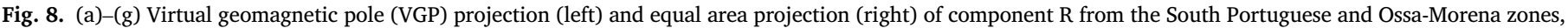

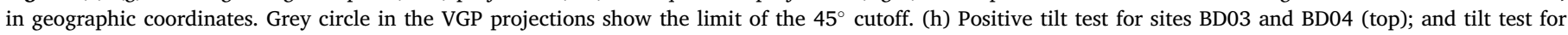
component R with sites BD03 and BD04 in tilt corrected coordinates (bottom). See text for details.

cut-off, again, improves the concentration parameter $(\mathrm{k}=9)$ but discarding once again a substantial number of samples (10 out of 24) (Fig. 9 and Table 1). Neither Py nor M pass a fold test (Supplementary File 1C). Due to their ambiguity and poor clustering we will exclude sites JaIb4 and JaIb5 (Cambrian limestones) from further interpretation.

The two sites of the QM series gave insightful results with respect to previous studies (Perroud et al., 1991; Parés and van der Voo, 1992). In site QM01, we identified two components (Fig. 10). The first one is well clustered with a single polarity, and with moderately shallow inclinations and declinations to the ESE (Fig. 10 and Table 1). This component shows the same declination and inclination as components "II" (Perroud et al., 1991) and "B" (Parés and van der Voo, 1992). It demagnetizes between 200 and $520^{\circ} \mathrm{C}$ (thermal) and 20-60 mT (AF) steps, and does not decay to the origin (Fig. 6). We refer to this component as $R_{1}$. Due to the presence of sulfides (likely pyrite) that alters to magnetite starting at $\sim 420{ }^{\circ} \mathrm{C}$, site QM01 samples do not provide any interpretable results at temperatures $>500{ }^{\circ} \mathrm{C}$ (e.g., Fig. 6, sample QM01-27). Nonetheless, we could identify another component that demagnetizes from $60 \mathrm{mT}$ to full demagnetization in AF. In general, this component is based only on 3 or 4 steps, in many cases with very low linearity, and MAD angles $>15^{\circ}$ (Fig. 6; Supplementary File 5). Nonetheless, we fitted it to mimic the procedure of previous studies in Almadén to be able to fully compare all data sets (Supplementary File 1C). However, previous authors also include thermal demagnetization in their interpretations despite the presence of sulfides. Our component shows poor clustering $(k=5)$, shallow inclinations with a single polarity and declinations to the ENE 


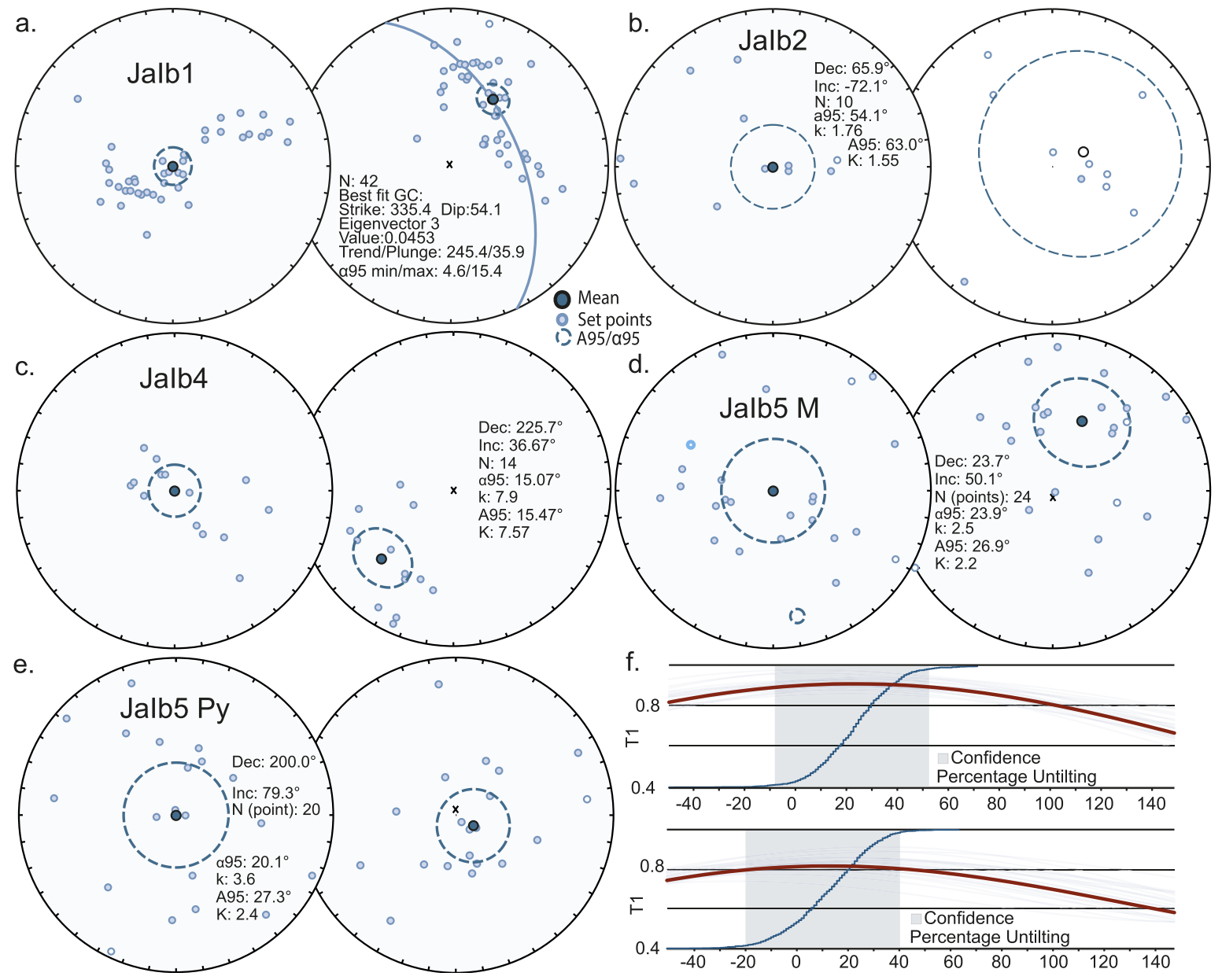

Fig. 9. (a)-(e) Virtual geomagnetic pole (VGP) projection (left) and equal area projection, in geographic coordinates (right) of directions observed in the Ossa-Morena Zone excluding eP component and present-day overprints (in Fig. 7 and Supplementary File 1C). Grey circle in the VGP projections shows the limit of the $45^{\circ}$ cutoff. (f) Fold tests for the folded outcrop of JaIb5-C, see text for details.

(Fig. 10; Table 1). We named this component $\mathrm{R}_{2}$, but cannot assure the reliability of this component and recommend caution in further usage.

In site QM02, we identified a component that again shows single polarity, NE declinations and shallow inclinations. This component shows a VGP distribution elongated in declination, in contrast to that expected at low latitudes, but it still passes the Deenen criteria (Deenen et al., 2011; Fig. 10 and Table 1). The component was isolated between $200{ }^{\circ} \mathrm{C}$ and $520{ }^{\circ} \mathrm{C}$ and $12-50 \mathrm{mT}(\mathrm{AF})$. After $520^{\circ} \mathrm{C}$ there is a loss of linearity. This component has a common true mean direction with component $\mathrm{R}_{2}$ of site QM01 in geographic coordinates (Supplementary File 1C) and does not pass a fold test (Fig. 10d). It is similar to the component "I" in the Silurian spilites and tuffs (our site QM02; Perroud et al., 1991) and Component "C" Parés and van der Voo (1992) identified in the Devonian dolerite (our site QM01).

\subsection{Significance of rock- and paleomagnetism}

Thermomagnetic analysis and hysteresis loops show that the main magnetic carrier is (Ti-)magnetite in the majority of all our sites. We found hematite in some samples of site BD01 and all of site JaIb01 (Fig. 4). Pyrite's presence was established in sites BD06, JaIb4, JaIb5 and QM01 from thermomagnetic analysis. Sites BD02, BD06 and JaIb5 show thermomagnetic curves that resemble greigite, especially the increase in magnetization after the $200{ }^{\circ} \mathrm{C}$ cycle would indicate that (Dekkers et al., 2000; Fig. 4). Site BD02 is a sedimentary jasper, with a strong red coloration, which suggests complete oxidation of iron to $\mathrm{Fe}^{3+}$. The samples from this site do not show magnetic decay corresponding to pyrrhotite, nor a Gyro-Remanent magnetization (GRM) effect in AF corresponding to greigite (Snowball, 1997). Therefore, magnetization carried by maghemite is the most reasonable interpretation.

\subsection{Anisotropy of the magnetic susceptibility}

AMS in the BD series shows in general terms a composite compactiontectonic AMS fabric (Fig. 6). In sites BD01 and BD03, the distributions of $\mathrm{k}_{\min }$ (roughly coincident with the pole to the bedding) and $\mathrm{k}_{\mathrm{int}}$ define a great circle (Fig. 6). This suggests an early stage of a composite compaction-tectonic fabric (Borradaile and Jackson, 2004). Sites BD07 and BD08, with oblate shape and $\mathrm{k}_{\min }$ perpendicular to the sub-vertical cleavage plane of the region (trending $\mathrm{N} 110^{\circ}$ ) define a full tectonic AMS fabric. The close to vertical $\mathrm{k}_{\max }$ may indicate little load during deformation which would facilitate upwards extension instead of orogen parallel extension as suggested by the stratigraphic sequence (e.g. Oliveira et al., 2019a, 2019b).

The JaIb series shows mostly composite fabrics with a sedimentary compaction element. In sites JaIb1, JaIb2, JaIb4 and JaIb5, the $\mathrm{k}_{\min }$ and $\mathrm{k}_{\max }$ axis are parallel to bedding poles and the local fold axes respectively. Site JaIb3 (gabbro) shows an isotropic fabric indicating little deformation (Fig. 6).

In the QM series, $\mathrm{k}_{\min }$ is perpendicular to D3 shear fragile-ductile foliation, which varies even between sites (see Aller et al., 1986). We could not observe any relic of a compaction fabric in the spilite and tuff 


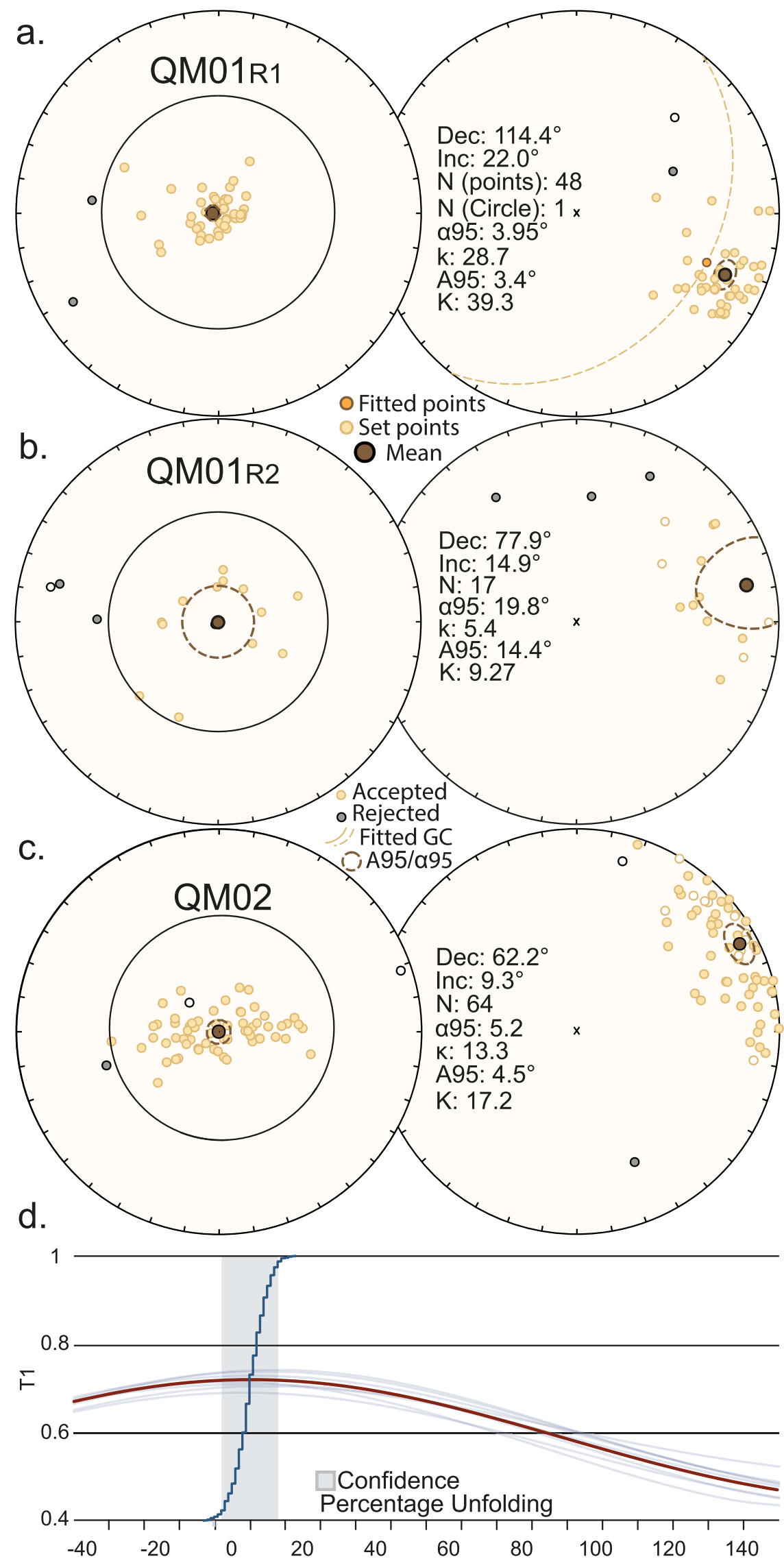

Fig. 10. (a)-(c) Virtual geomagnetic pole (VGP) projection (left) and equal area projection (right) of component R observed in the Almadén syncline (SE Central Iberian Zone), in geographic coordinates. Grey circle in the VGP projections show the limit of the $45^{\circ}$ cutoff. (d) Negative fold test for component $R_{2}$. 
Table 1

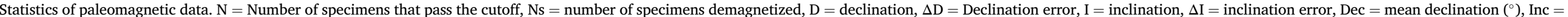

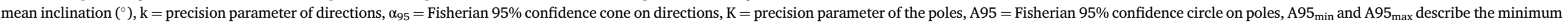
and maximum values of A95 allowed to consider the average representative, $\lambda=$ paleolatitude, N/A $=$ Not Available.

\begin{tabular}{|c|c|c|c|c|c|c|c|c|c|c|c|c|c|c|c|c|c|c|c|c|c|}
\hline \multirow[t]{2}{*}{ Code } & \multirow[t]{2}{*}{ Component } & \multirow[t]{2}{*}{ Latitude $\left({ }^{\circ}\right)$} & \multirow[t]{2}{*}{ Longitude $\left(^{\circ}\right)$} & \multirow{2}{*}{$\begin{array}{l}\begin{array}{l}\text { In situ } \\
\text { statistics }\end{array} \\
\mathrm{N}\end{array}$} & \multirow[b]{2}{*}{ Ns } & \multirow[b]{2}{*}{$\mathrm{D}$} & \multirow[b]{2}{*}{$\Delta \mathrm{D}$} & \multirow[b]{2}{*}{ I } & \multirow[b]{2}{*}{$\Delta \mathrm{I}$} & \multirow[b]{2}{*}{$\mathrm{k}$} & \multirow[b]{2}{*}{$\alpha_{95}$} & \multirow[b]{2}{*}{$\mathrm{K}$} & \multirow[b]{2}{*}{ A95 } & \multirow[b]{2}{*}{$\mathrm{A} 95_{\min }$} & \multirow[b]{2}{*}{$\mathrm{A} 95_{\max }$} & \multirow[b]{2}{*}{$\lambda$} & \multirow{2}{*}{$\begin{array}{l}\begin{array}{l}\text { Tilt } \\
\text { corrected }\end{array} \\
\text { Dec }\end{array}$} & \multirow[b]{2}{*}{ Inc } & \multirow[t]{2}{*}{$\begin{array}{l}\text { Strike } \\
\left({ }^{\circ}\right)\end{array}$} & \multirow[t]{2}{*}{$\begin{array}{l}\text { Dip } \\
\left({ }^{\circ}\right) \\
\end{array}$} & \multirow{2}{*}{$\frac{\text { Orogen }}{\text { strike }}$} \\
\hline & & & & & & & & & & & & & & & & & & & & & \\
\hline BD01 & $\mathrm{R}$ & 38.027135 & -8.430202 & 24 & 24 & 100.5 & \pm 4.94 & 9.68 & \pm 9.64 & 25.55 & 5.97 & 37.05 & 4.93 & 3.37 & 11.07 & 4.88 & 108.12 & -19.64 & 329 & 73 & 131 \\
\hline \multirow[t]{2}{*}{ BD03 } & $\mathrm{R}$ & 37.349000 & -8.321500 & 46 & 46 & 144.25 & \pm 3.04 & 21.58 & \pm 5.37 & 38.72 & 3.42 & 50.56 & 2.99 & 2.59 & 7.35 & 11.18 & & & 320 & 56 & 142 \\
\hline & R TC & & & 46 & 46 & 123.98 & \pm 3.03 & 15.24 & \pm 5.69 & 38.72 & 3.42 & 50.06 & 3 & 2.59 & 7.35 & 7.76 & & & & & \\
\hline \multirow[t]{2}{*}{ BD04 } & $\mathrm{R}$ & 38.474855 & -8.342927 & 36 & 36 & 123.93 & \pm 4.68 & 27.82 & \pm 7.58 & 18.37 & 5.73 & 28.81 & 4.53 & 2.86 & 8.58 & 14.78 & & & 21 & 21 & 143 \\
\hline & R TC & & & 36 & 36 & 122.51 & \pm 3.81 & 7.29 & \pm 7.52 & 18.37 & 5.73 & 40.35 & 3.81 & 2.86 & 8.58 & 3.66 & & & & & \\
\hline BD05 & $\mathrm{R}$ & 37.567819 & -7.529237 & 7 & 7 & 140.32 & \pm 7.07 & 23.07 & \pm 12.24 & 74.31 & 7.05 & 77.09 & 6.92 & 5.51 & 24.07 & 12.02 & 114.08 & 32.98 & 296 & 47 & 115 \\
\hline BD06 & $\mathrm{R}$ & 37.651908 & -6.888124 & 10 & 10 & 107.89 & \pm 9.12 & 10.62 & \pm 17.7 & 23.5 & 10.18 & 29.25 & 9.08 & 4.78 & 19.22 & 5.36 & 109.87 & -8.37 & 98 & 83 & 110 \\
\hline BD07 & $\mathrm{R}$ & 37.644066 & -6.817216 & 10 & 10 & 100.82 & \pm 5.65 & 7.14 & \pm 11.15 & 56.58 & 6.48 & 74.37 & 5.64 & 4.78 & 19.22 & 3.59 & 102.61 & -4.83 & 94 & 76 & 110 \\
\hline JaIb1 & ChRM & 38.039423 & -6.725365 & 42 & 42 & 19.88 & \pm 7.29 & 42.45 & \pm 8.72 & 16.62 & 6.42 & 15.69 & 6.63 & 3 & 9.24 & 24.58 & 171.76 & 47.68 & 100 & 80 & \\
\hline \multirow[t]{2}{*}{ JaIb2 } & $\mathrm{R}$ & 38.069928 & -6.702366 & 11 & 11 & 94.48 & \pm 7.34 & -0.99 & \pm 14.68 & 18.24 & 10.98 & 39.66 & 7.34 & 4.6 & 18.1 & -0.5 & 94.48 & -0.99 & 0 & 0 & 112 \\
\hline & Raw & & & 10 & 10 & 65.91 & $\pm \mathrm{N} / \mathrm{A}$ & -72.09 & \pm 40.43 & 1.76 & 54.1 & 1.55 & 63 & 4.78 & 19.22 & -57.13 & 65.91 & -72.09 & & & \\
\hline JaIb4 & ChRM & 37.988208 & -5.632529 & 14 & 14 & 225.71 & \pm 16.54 & 36.67 & \pm 22.66 & 7.92 & 15.07 & 7.57 & 15.47 & 4.18 & 15.55 & 20.42 & 129.84 & 61.31 & 345 & 67 & \\
\hline \multirow[t]{4}{*}{ JaIb5 } & Py & 37.894504 & -5.632144 & 20 & 20 & 119.99 & $\pm \mathrm{N} / \mathrm{A}$ & 79.28 & \pm 15.07 & 3.61 & 20.12 & 2.41 & 27.3 & 3.62 & 12.42 & 69.26 & & & & & \\
\hline & Ру ТC & & & 20 & 20 & 328.7 & $\pm \mathrm{N} / \mathrm{A}$ & 79.33 & \pm 14.86 & 3.43 & 20.83 & 2.44 & 26.95 & 3.62 & 12.42 & 69.36 & & & & & \\
\hline & M & 37.894504 & -5.632144 & 24 & 24 & 23.72 & \pm 31.80 & 50.09 & \pm 30.05 & 2.52 & 23.87 & 2.19 & 26.89 & 3.37 & 11.07 & 30.87 & & & & & \\
\hline & M TC & & & 24 & 24 & 356.83 & \pm 43.26 & 51.82 & \pm 37.91 & 1.95 & 30.02 & 1.68 & 35.33 & 3.37 & 11.07 & 32.45 & & & & & \\
\hline QM01 & $\mathrm{R}_{1}$ & 38.802386 & -4.802181 & 47 & 49 & 114.05 & \pm 3.43 & 21.99 & \pm 6.02 & 28.71 & 3.95 & 39.26 & 3.36 & 2.57 & 7.25 & 11.41 & 114.05 & 21.99 & 0 & 0 & 96 \\
\hline & $\mathrm{R}_{2}$ & 38.802386 & -4.802181 & 13 & 17 & 77.91 & \pm 14.52 & 14.86 & \pm 27.3 & 5.37 & 19.76 & 9.27 & 14.39 & 4.3 & 16.29 & 7.56 & 27.01 & 14.86 & 0 & 0 & 96 \\
\hline QM02 & $\mathrm{R}_{2}$ & 38.773787 & -4.786961 & 61 & 64 & 62.21 & \pm 4.53 & 9.3 & \pm 8.85 & 13.33 & 5.18 & 17.23 & 4.51 & 2.32 & 6.15 & 4.68 & 43.02 & 12.2 & $262 / 216$ & $76 / 85$ & 96 \\
\hline eP & & & & 104 & 104 & 160.62 & \pm 2.52 & 1.6 & \pm 5.03 & 23.63 & 2.91 & 31.27 & 2.52 & 1.87 & 4.4 & 0.8 & & & & & \\
\hline eP TC & & & & 91 & 104 & 148.34 & \pm 3.75 & 20.67 & \pm 6.69 & 11.26 & 4.63 & 17.15 & 3.69 & 1.97 & 4.78 & 10.68 & & & & & \\
\hline PD & & & & 282 & 301 & 359.43 & \pm 2.99 & 56.53 & \pm 2.28 & 19.68 & 1.94 & 13.3 & 2.39 & 1.26 & 2.35 & 37.1 & & & & & \\
\hline PD TC & & & & 214 & 301 & 2.91 & \pm 3.03 & 6.38 & \pm 6.00 & 6.94 & 3.95 & 11.1 & 3.03 & 1.4 & 2.79 & 3.2 & & & & & \\
\hline
\end{tabular}


sequences that previous studies attributed to it (Perroud et al., 1991). We interpret the QM series' AMS as a tectonic fabric.

\subsection{Paleomagnetism}

At the South Portuguese and Ossa-Morena zones we have identified three main magnetization components: PD, eP and R. We interpret the PD component (in geographic coordinates) as a viscous remanent magnetization, with the direction of the 'present day field' (Bruhnes geocentric axial dipole (GAD)) in Iberia. The eP component (in sites BD01, BD03, BD06, BD07, BD08, JaIb2 and JaIb3) has a single polarity and very shallow inclinations (Fig. 7a), which implies its acquisition occurred at a time when Iberia was located at equatorial latitude. It is coherent regionally, showing no differential rotations, clusters far better in geographic coordinates than in stratigraphic coordinates (Fig. 7b, Table 1), and shares a common true mean direction with primary early Permian magnetizations elsewhere in Iberia (Fig. 7c; Weil et al., 2019). We interpret $\mathrm{eP}$ as a post-orogenic, early Permian component acquired during the Kiaman reversed superchron (314-264 Ma, e.g. Langereis et al., 2010), at a time when western Iberia was a stable plate segment.

Component $\mathrm{R}_{1}$ (site QM01) shows very similar inclinations and declinations to the components described in previous studies (Perroud et al., 1991; Parés and van der Voo, 1992). Due to the single polarity, shallow inclinations and CCW rotations, both previous studies attributed this component to a late Carboniferous remagnetization. Pastor-Galán et al. (2015b) re-interpreted this component as a syn-Cantabrian Orocline remagnetization since the rotations were coherent with the Cantabrian Orocline but smaller than the expected rotation. We support such interpretation.

We identified component $\mathrm{R}_{2}$ in both Devonian dolerites and Silurian volcanics (sites QM01 and 02 respectively). Our interpretation of $R_{2}$ in site QM01 (Devonian dolerite) is fairly bold, giving the poor linearity of the weak final 3-4 demagnetization steps. Parés and van der Voo (1992) identified a similar component with a linear fit of three thermal steps in the same outcrop $\left(500,550\right.$ and $\left.600{ }^{\circ} \mathrm{C}\right)$. Despite the better thermal resolution $\left(20^{\circ} \mathrm{C}\right.$ steps from $\left.500{ }^{\circ} \mathrm{C}\right)$, we could not retrieve the component with thermal demagnetization: thermochemical alteration precluded its determination (Fig. 6). Considering the presence of sulfides, our AF data in QM01 might be more reliable than the thermal demagnetization. Although it should be taken with caution, our data in site QM01 seem to share a common true mean direction with $R_{2}$ in site QM02. $R_{2}$ is also very similar to what Perroud et al. (1991) found in the Silurian spilites before any correction. We found the same declination $\left(62^{\circ}\right)$ and the same inclinations in the sites they sampled previously. Perroud et al. (1991) interpreted this component as Silurian in origin because of a potential better clustering after correcting for the eastern plunging axis of the Almadén syncline. However, we sampled sites from the hinge and southern limb of the syncline where the fold axis is

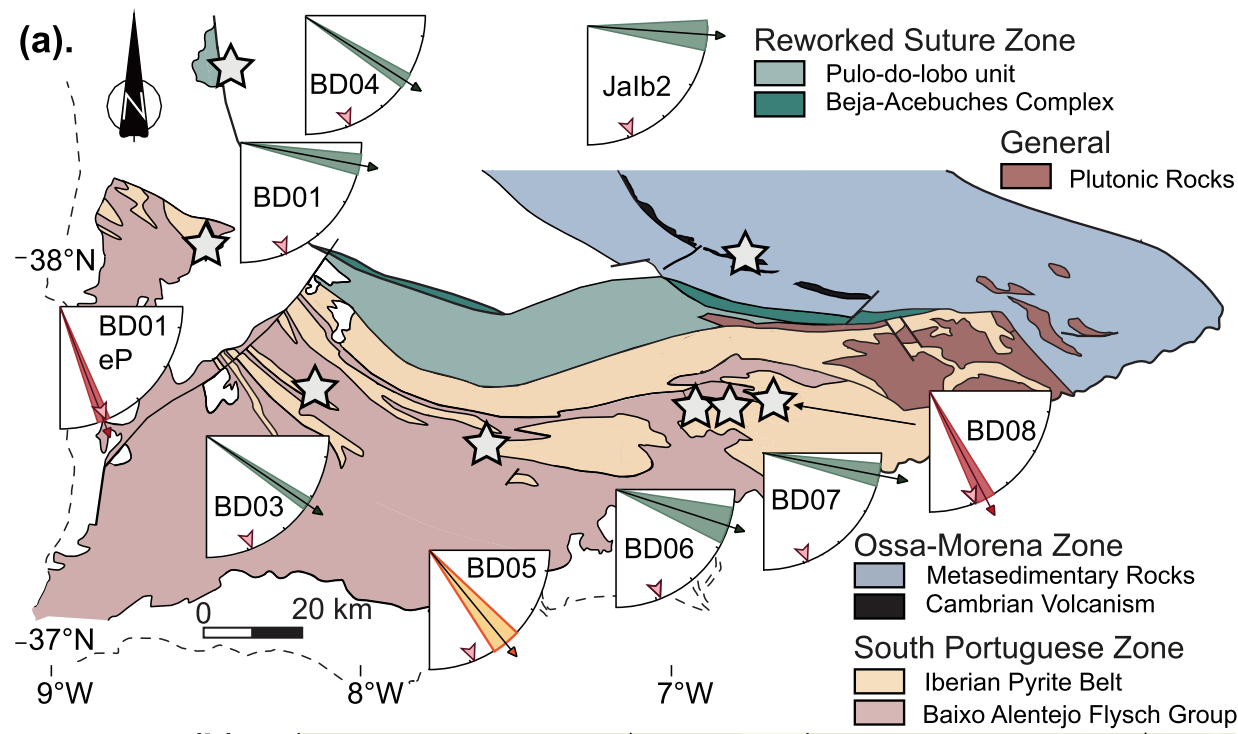

(b).

\section{Declinations \\ $\checkmark$ Exp.Permian dec \\ $\triangle$ Observed dec. \\ $\nabla$ Dec. Confidence \\ Sites

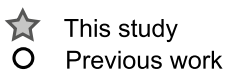

Structures

4 Shear band

$\nabla$ Syncline

Almadén Declinations
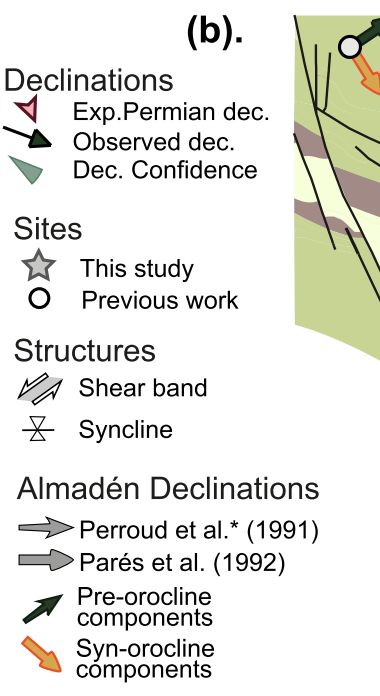

$2 \mathrm{~km}$
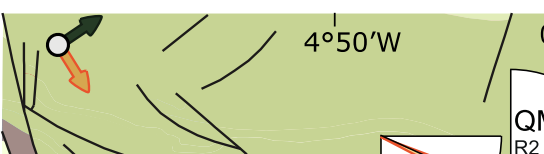

ixo Alentejo Flysch Group

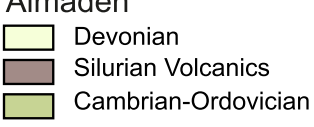

Fig. 11. (a) Declinations and parachute of confidence $(\Delta \mathrm{Dec}$ ) of component $\mathrm{R}$ in the South Portuguese and Ossa-Morena zones. Small red arrow shows the declination of the eP component. (b) Compilation of all paleomagnetic declination data in the Almadén syncline (SE Central Iberian Zone). Green arrows indicate the pre-orocline directions of components $R_{2}$ (this study), II (Perroud et al., 1991) and C (Parés and van der Voo, 1992). Orange arrows indicate syn-orocline formation components: $\mathrm{R}_{1}$ (this study), B (Parés and van der Voo, 1992) and I (Perroud et al., 1991). 
horizontal and tilt correction is straightforward. $\mathrm{R}_{2}$ does not pass a bootstrapped fold test (Fig. 10d; Tauxe, 2010). The $\mathrm{R}_{2}$ component in the Almadén region is post-folding, and therefore post-Variscan D1 (post-340 Ma). We, therefore, consider $\mathrm{R}_{1}$ and $\mathrm{R}_{2}$ part of a general late Carboniferous rotated component of the South Portuguese and Ossa-Morena zones, ' $\mathrm{R}$ ' sensu lato (Fig. 11b).

Component R (s.l.) shows a single polarity and shallow downward inclinations, albeit slightly steeper than those of the eP component. We have corrected for the tilt of sites BD03 and BD04 due to better clustering (Supplementary File 1C), in particular the inclinations are much more consistent. The inclinations of sites BD03 and BD04 before any tilt correction are too steep to be a post-Variscan magnetization (Pastor-Galán et al., 2016; Fig. 8h), and their declinations are too much rotated to be post-early Permian (eP). Component $\mathrm{R}$ shows CCW rotations of different magnitude (from $20^{\circ}$ in BD05 up to $70^{\circ}$ in JaIb2) (Fig. 11a) with respect to component $\mathrm{eP}$. The rotation pattern implies differential vertical axis rotations within SW Iberia, which must have occurred during a protracted period of constant polarity, and prior to the acquisition of eP. In general terms we can define component $\mathrm{R}$ as a post-deformation, shallow and single polarity component that had to be acquired prior to $295 \mathrm{Ma}$ (the timing of the eP component, cf. Weil et al., 2013). This constrains the acquisition of $\mathrm{R}$ to $\sim 314$ Ma to $\sim 295$ Ma, i.e. during Kiaman superchron, which explains its single polarity.

\subsection{Kinematic implications for the Variscan belt}

The timing of magnetization and counterclockwise rotations in SW Iberia from the results of this work, for component $\mathrm{R}$, correspond to those observed elsewhere in the Cantabrian Orocline's southern limb (e.g. Pastor-Galán et al., 2011, 2015b, 2018). Structural and paleomagnetic studies have shown that Western Iberia registered no major post-Variscan deformation and/or differential rotation events (e.g. Weil et al., 2019). Our eP component coincides with the primary magnetization in the nearby El Viar basin and fits with the expected direction for stable Iberia during the Permian (Fig. 7; Weil et al., 2010). Our results show that the South Portuguese, Ossa-Morena and the south Central Iberian zones rotated up to $70^{\circ} \mathrm{CCW}$ during the late Carboniferous-early Permian. In the South Portuguese Zone, the amount of rotation seems to correlate with the strike of the orogen suggesting differential vertical axis rotations and orocline bending (Fig. 10a; e.g. Schwartz and Van der Voo, 1983). This agrees with previous paleomagnetic studies to the north (Weil et al., 2013; Pastor-Galán et al., 2015b, 2016, 2017a, 2018; Fernández-lozano et al., 2016), proving that most of Iberia, except its northernmost region, comprises the southern limb of the Cantabrian Orocline (Fig. 2a). Altogether, paleomagnetic results from Iberia rule out the Central Iberian curve as a coeval orocline to the south of the Cantabrian Orocline, which would require opposite sense, CW late Carboniferous vertical axis rotations.

The orocline test indicates the degree of differential vertical axis rotations underwent by differently striking orogenic segments. After plotting declination vs. strike, the best linear fit slope is 1 when all curvature is the result of orocline bending, and it is 0 if the curvature is not due to any vertical axis rotations (Schwartz and Van der Voo, 1983; Pastor-Galán et al., 2017a). Several authors have shown the secondary nature of the Cantabrian Orocline with an orocline test based on a substantial number of structural (e.g. Pastor-Galán et al., 2011) and paleomagnetic data (e.g. Weil et al., 2013). When the orocline test is well constrained by a multitude of data points, as in the Cantabrian Orocline (Weil et al., 2013), it is possible to infer the expected declination in a portion of the orocline knowing its strike. We calculated reference declinations and uncertainties for all our sites with component $\mathrm{R}$ (s.1.) assuming they were part of the southern limb of Cantabrian Orocline using the procedure of Pastor-Galán et al. (2017b) (Supplementary Tables 1 and 2). After calculating the expected declination for each site, we compared our $\mathrm{R}$ declination with both the expected declination and with our eP component, which marks the expected declination at the end of the Cantabrian Orocline rotations.

Indeed, the R components in sites BD01, 03, 04, 06, 07, JaIb2, QM01 and 02 , show rotations in agreement with those expected for such strike in the southern limb of the Cantabrian Orocline (Fig. 12). The $\mathrm{R}$ component in site BD05 and component $\mathrm{R}_{1}$ in site QM01 show less rotation than expected and lie between the expected declination and the eP component. We interpret that these components were acquired during the rotation phase that led to the Cantabrian Orocline. Therefore, they registered only a portion of the rotation rather than the full rotation, in a process similar to that described in Pastor-Galán et al. (2016, 2017b).

The sense and magnitude of the vertical axis rotations observed in SW Iberia imply that the Laurussian segment of Iberia (South Portuguese Zone) moved together with the southern limb of the Cantabrian Orocline. When we restore backwards the rotation implied by paleomagnetism, the South Portuguese Zone remains roughly parallel to the general trend of the Variscan orogen before the orocline formation (Fig. 13) leaving little space for any significant promontory. In addition, the South Portuguese Zone shows over $90^{\circ}$ of CCW rotation when compared to NW Europe Laurussian terrains (e.g. Pastor-Galán et al., 2015a) indicating their strike was roughly parallel previous to the late Carboniferous. Our kinematic constraints are incompatible to a 'Laurussian rigid indenter into Gondwana' hypothesis (e.g. Simancas et al., 2013) as the mechanism that formed the Cantabrian Orocline.

This leaves a change in the stress field group of hypotheses, from orogen perpendicular to orogen parallel compression, as the only plausible scenario to explain the presently available data sets (e.g. Gutiérrez-Alonso et al., 2004, 2008a; Pastor-Galán et al., 2015a, b; Weil et al., 2019). At the same time, paleomagnetism from SW Iberia corroborates that the Cantabrian Orocline extended into both Gondwana (e.g. Cantabrian, West Asturian-Leonese, Central Iberian and Ossa Morena zones) and Laurussia (South Portuguese Zone and the Munster Basin in Ireland) in its northern and southern limbs, confirming the Greater Cantabrian orocline hypothesis that supports a transcontinental orocline formation (Fig. 13; Pastor-Galán et al., 2015a).

Our results do not show stronger CCW rotations in the sites located closer to the main sinistral shear zones suggesting that narrow shear zones accommodated the late Carboniferous-early Permian sinistral movement in SW Iberia. In addition, geochronological and structural data from the sinistral shear zones bounding Ossa-Morena Zone indicate that their main sinistral displacement happened prior to $\sim 315 \mathrm{Ma}$, when our paleomagnetic constraints begin (Quesada and Dallmeyer, 1994; Pérez-Cáceres et al., 2015).

The Variscan-Alleghanian orogen becomes younger westwards (e.g. Pastor-Galán et al., 2020), the Galicia-Trás-os-Montes Zone apparently emplaced from east to west during collision (Dias da Silva et al., 2020), and the sinistral zones of SW Iberia were active at least from $340 \mathrm{Ma}$ (Quesada and Dallmeyer, 1994). Although kinematic evidence is still scarce, in our opinion orogen parallel transport of units escaping from collision at the eastern side of the orogen can explain the formation of an early Carboniferous curved structure in Central Iberia and the left-lateral movements in SW Iberia (e.g. Murphy et al., 2016; Pastor-Galán et al., 2020). Structural data in the Central Iberian Zone suggest a D1 (early Carboniferous) origin for the Central Iberian curve (Azor et al., 2019; Pastor-Galán et al., 2019b; Dias da Silva et al., 2020). Dias da Silva et al. (2020) argue that the Galicia-Trás-os-Montes Zone is an early Carboniferous thin-skinned extrusion wedge that moved orogen-parallel. This movement would then have formed the Central Iberian curve, possibly restricted to the surroundings of Galicia-Trás-os-Montes Zone. In a similar fashion but at a 'both margins scale', Murphy et al. (2016) suggested that an oblique or irregular margin collision between Gondwana and Laurussia was responsible for early Carboniferous extrusion of different blocks in SW Iberia. This movement could explain the pre-Cantabrian Orocline left-lateral movements observed in SW Iberia (e.g. Pastor-Galán et al., 2020).

Fig. 13 sketches a simplified kinematic model for the evolution of the Greater Cantabrian Orocline that affected the margins of both Gondwana 

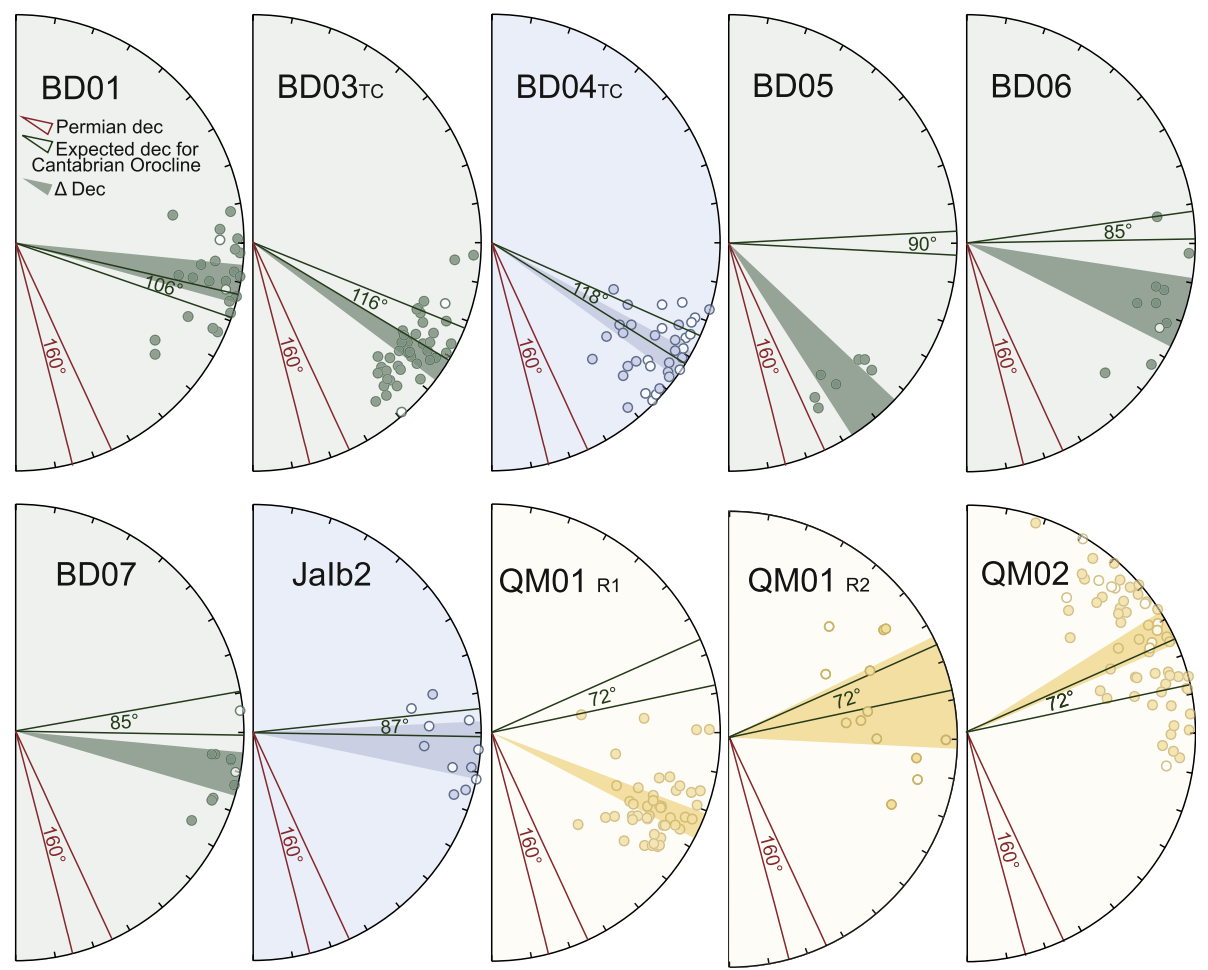

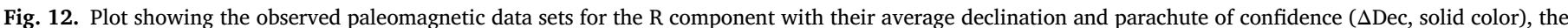

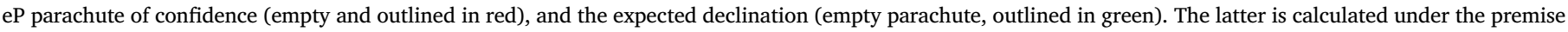
that each site rotated together with the southern limb of the Cantabrian Orocline. We followed the procedure of Pastor-Galán et al. (2017b).

and Laurussia from a roughly linear orogen (Fig. 13a) to its present shape (Fig. 13d). Following the available data (e.g. Weil et al., 2019) we suggest that the vertical axis rotation initiated between ca. 315-310 Ma (Fig. 13a), during the D3 deformation phase. With the protracted orogen-parallel shortening, the orogen began to buckle around a vertical axis. Dextral shear zones with some sinistral conjugates, shortening (especially at the orocline core) and vertical axis rotations, accommodated the deformation (Fig. 13b). The magmatism that accompanied the formation of the Cantabrian Orocline (Gutiérrez-Alonso et al., 2011; Pereira et al., 2014) caused pervasive remagnetizations which recorded intermediate-rotation directions, such as component $\mathrm{R}_{1}$ in Almadén, or component R in site BD05 in the South Portuguese Zone (Fig. 13c). At early Permian times, the orocline is tight and there is no space to accommodate vertical axis rotations (Weil et al., 2010; Pastor-Galán et al., 2011); at that time crustal scale NE-SW faults formed (Fernández-Lozano et al., 2019).

The amount and quality of the kinematic observations indicating a secondary origin for the Greater Cantabrian Orocline are difficult to dispute. The Greater Cantabrian Orocline had limbs of at least $1700 \mathrm{~km}$ wide and $3000 \mathrm{~km}$ length, crosscutting two continents and several major lithospheric scale structures. The Greater Cantabrian Orocline, including most of Avalonia (s.1.), surpasses all traditional limits: the crustal scale shear zones in the Variscan hinterland (Weil et al., 2013; Gutiérrez-Alonso et al., 2015) and the Rheic Ocean suture (Ribeiro et al., 2007; Weil et al., 2010; Martínez-Catalán, 2011). At the same time, the formation of the structure requires well over $1000 \mathrm{~km}$ of extension and shortening in a relatively short period of time. Structures accommodating convergence and extension are yet to be described, including large shear zones (like the putative shear zone in Fig. 13), crustal scale detachments and/or subduction zones. Potential areas accommodating shortening include the Picos de Europa (Merino-Tomé et al., 2009), Pyrenees and other areas in southern France or Italy (Pereira et al., 2014). Extension, however, is elusive. Sandoval et al. (2019) found that the Atlantic conjugate margins of Iberia and Newfoundland were already extended during Triassic times, before the extension that led to the opening of the Atlantic. This is, perhaps, a plausible candidate place to have accommodated part of the extension.

Finding a mechanism causing the necessary far-field stress change to form such a curved structure remains challenging. Most proposed models slightly modify previous plate reconstructions (Stampfli et al., 2013; Domeier and Torsvik, 2014) taking a smaller scale orocline as their starting point (Gutiérrez-Alonso et al., 2004, 2008a; Weil et al., 2010; Pastor-Galán et al., 2015b). The formation of a Greater Cantabrian Orocline questions not only the mechanisms proposed for its formation, but also challenges the existing late Carboniferous plate reconstructions (e.g. Stampfli et al., 2013; Domeier and Torsvik, 2014). Finally, one of the main assumptions in plate tectonics, plate rigidity (Gordon, 1998; Torsvik et al., 2012), should be queried and put to further testing.

\section{Conclusions}

(1) We performed the first comprehensive paleomagnetic study in SW Iberia to study late Carboniferous vertical-axis rotations. We found two remagnetization events in SW Iberia, labelled components $\mathrm{eP}$ and $\mathrm{R}$. Component $\mathrm{eP}$ is a reversed shallow single polarity component, coincident with the early Permian pole of Iberia. We interpreted it as an early Permian remagnetization. $\mathrm{R}$ is also a reversed shallow single polarity component, but less shallow than eP. We interpret component $\mathrm{R}$ to have been acquired prior to eP but during the Kiaman superchron as well, with a prospective age of ca. 315-290 Ma. Component R shows counterclockwise rotations between $30^{\circ}$ and $70^{\circ}$ in comparison to component $\mathrm{eP}$.

(2) The determined counterclockwise rotations are coeval and of the same magnitude to those observed in the southern limb of the Cantabrian Orocline. Thus, all of SW Iberia was part of the southern limb of the Cantabrian Orocline. We conclude that the Central Iberian curve is neither coeval nor genetically linked to the Cantabrian Orocline. 
(a) ca. $310 \mathrm{Ma}$

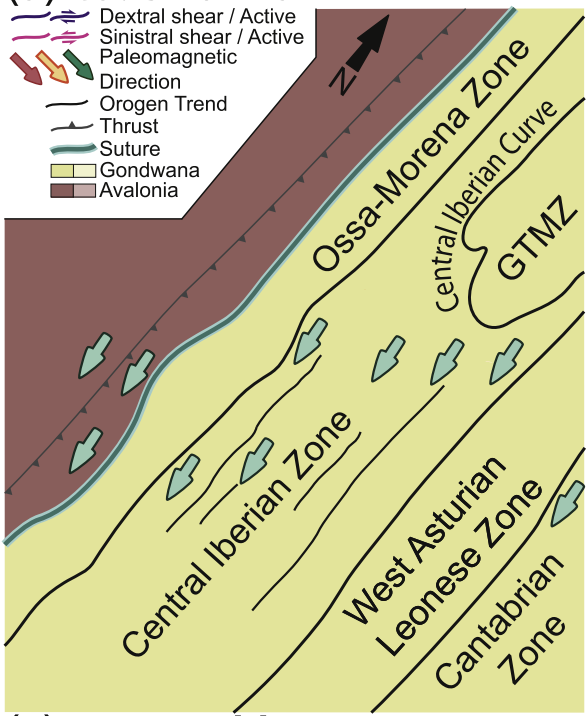

(b) ca. $307 \mathrm{Ma}$

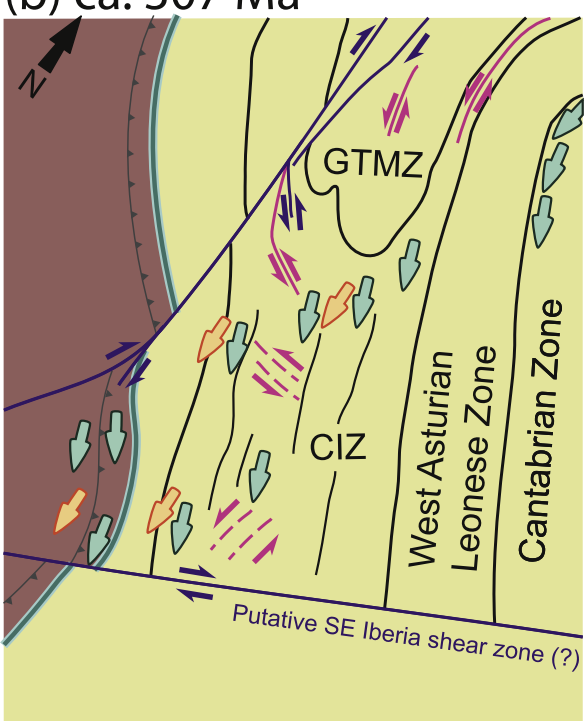

(d) ca. $295 \mathrm{Ma}$
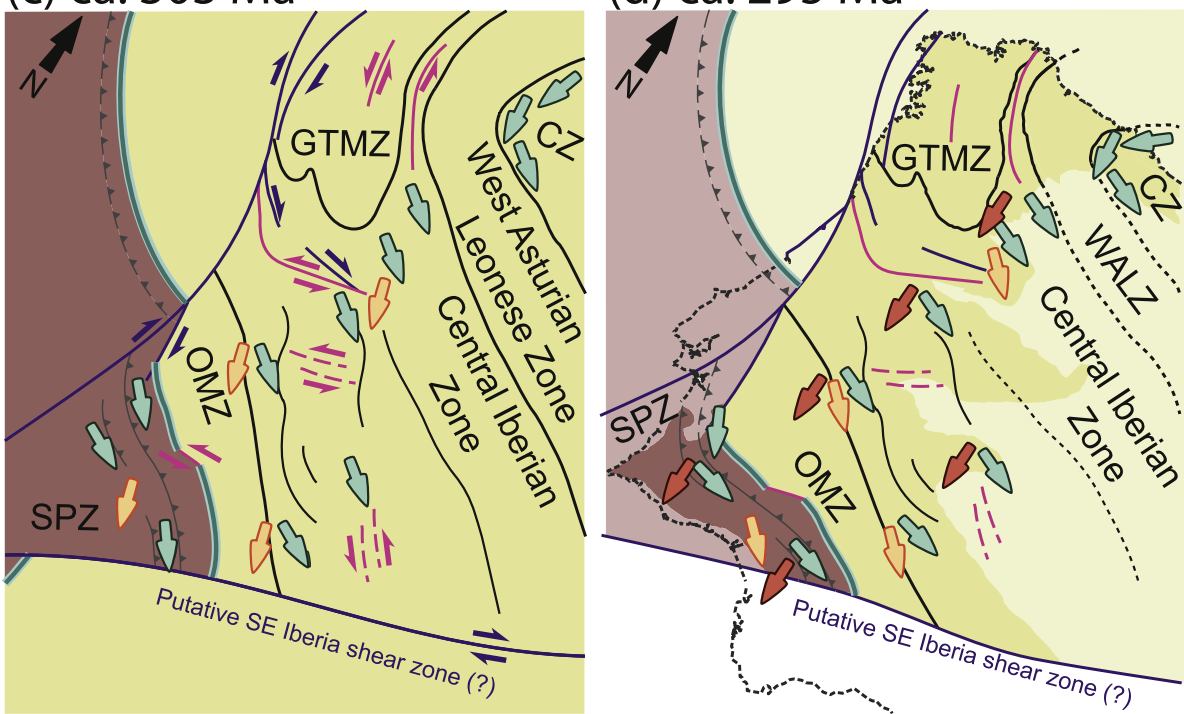

Fig. 13. Cartoon depicting the kinematic and paleomagnetic evolution of the Greater Cantabrian Orocline between $\sim 310 \mathrm{Ma}$ and $\sim 295 \mathrm{Ma}$. (a) Ca. $310 \mathrm{Ma}$ - A roughly linear Variscan orogen (NS in present-day coordinates) showing all pre-orocline declinations. At this time the Cantabrian Orocline begun to bend/ buckle, perhaps due to a change in the stress field (e.g. Gutiérrez-Alonso et al., 2008). (b) Ca. 307 Ma - While the Cantabrian orocline buckled a series of major dextral and sinistral shear zones developed to accommodate part of this rotation (e.g. Gutiérrez-Alonso et al., 2015). Pervasive remagnetizations (orange arrows) occurred during the entire period (e.g. Pastor-Galán et al., 2017b), possibly due to the widespread magmatism in the Central Iberian Zone (e.g. Gutiérrez-Alonso et al., 2011). (c) Ca. 303 Ma The protracted buckling event also bent the shear zones. (d) Ca. $295 \mathrm{Ma}$ - Permian paleomagnetism indicates that no further vertical axis rotations occurred from this time (red arrows).
(3) Kinematics of SW Iberia imply that the South Portuguese Zone (of Laurussian affinity) rotated together with the rest of the Cantabrian Orocline. Therefore, we rule out an Avalonian South Portuguese rigid-indenter as a buckling mechanism of the Cantabrian Orocline.

(4) The rotations involved in the formation of the Cantabrian Orocline trespassed the Rheic suture and several lithospheric scale structures both in its northern and southern limb confirming the hypothesis of a $1700 \mathrm{~km}$ wide and $3000 \mathrm{~km}$ long continental scale Greater Cantabrian Orocline.

\section{Declaration of competing interest}

The authors declare that they have no known competing financial interests or personal relationships that could have appeared to influence the work reported in this paper.

\section{Acknowledgments}

We thank Ícaro Fróis Dias da Silva, Paulo Carlos, Saturnino Lorenzo Álvarez, Fábio Marques, André Torres and the Centro Ciência Viva do Lousal, for their field assistance. We thank Ícaro Fróis Dias da Silva, Irene
Perez-Cáceres and Francisco Pereira for their constructive reviews and comments. BDLM, MJD, and WK are grateful for support by Utrecht University. This contribution is related to the ISES post-doctoral grant to DPG (Project No. WA.146101.2.656). BDLM would like to thank Guilherme Ínsua-Pereira for the valuable exchanges of ideas. DPG expresses gratitude to David Robert Jones: the starman, the goblin king, a one-day hero. The present work is a contribution to IUGS-UNESCO's IGCP Projects No. 574 "Bending and Bent Orogens, and Continental Ribbons", No. 597 "Amalgamation and Breakup of Pangaea" and No. 648 "Supercontinent Cycles \& Global Geodynamics".

\section{Appendix A. Supplementary data}

Supplementary data associated with this article can be found, in the online version, at https://doi.org/10.1016/j.gsf.2020.07.013.

\section{References}

Accotto, C., Martínez Poyatos, D., Azor, A., Jabaloy-Sánchez, A., Talavera, C., Evans, N.J., Azdimousa, A., 2020. Tectonic evolution of the Eastern Moroccan Meseta: from late Devonian fore-arc sedimentation to early Carboniferous collision of an Avalonian promontory. Tectonics 38, e2019TC005976. https://doi.org/10.1029/ 2019 tc005976. 
Aerden, D.G.A.M., 2004. Correlating deformation in Variscan NW-Iberia using porphyroblasts; implications for the Ibero-Armorican Arc. J. Struct. Geol. 26 , 177-196. https://doi.org/10.1016/S0191-8141(03)00070-1.

Aller, A., Bastida Ibáñez, J., Ortega Bernaldo de, Quirós, Eduardo, F., Estaun, P., 1986. Aportación al conocimiento estructural del Sinclinal de Almadén. Bol. Geol. Min. 97, 68-81 (in Spanish with English abstract).

Arenas, R., Díez Fernández, R., Rubio Pascual, F.J., Sánchez Martínez, S., Martín Parra, L.M., Matas, J., González del Tánago, J., Jiménez-Díaz, A., Fuenlabrada, J.M., Andonaegui, P., Garcia-Casco, A., 2016. The Galicia-Ossa-Morena Zone: proposal for a new zone of the Iberian Massif. Variscan implications. Tectonophysics 681, 135-143. https://doi.org/10.1016/j.tecto.2016.02.030.

Azor, A., Dias da Silva, Í., Gómez Barreiro, J., González-Clavijo, E., Martínez Catalán, J.R. Simancas, J.F., Martínez Poyatos, D., Pérez-Cáceres, I., González Lodeiro, F. Expósito, I., Casas, J.M., Clariana, P., García-Sansegundo, J., Margalef, A., 2019. Deformation and structure. In: Quesada, C., Oliveira, J. (Eds.), The Geology of Iberia: A Geodynamic Approach. Regional Geology Reviews. Springer, Cham, pp. 307-348. https://doi.org/10.1007/978-3-030-10519-8_10.

Azor, A., Rubatto, D., Simancas, J.F., González Lodeiro, F., Martínez Poyatos, D., Martín Parra, L.M., Matas, J., 2008. Rheic Ocean ophiolitic remnants in southern Iberia questioned by SHRIMP U-Pb zircon ages on the Beja-Acebuches amphibolites. Tectonics 27 (5), TC5006. https://doi.org/10.1029/2008TC002306.

Ballèvre, M., Martínez Catalán, J.R., López Carmona, A., Pitra, P., Abati, J., Díez Fernández, R., Ducassou, C., Arenas, R., Bosse, V., Castiñeiras, P., FernándezSuárez, J., Gómez Barreiro, J., Paquette, J.L., Peucat, J.J., Poujol, M., Ruffet, G., Sánchez Martínez, S., 2014. Correlation of the nappe stack in the Ibero-Armorican arc across the Bay of Biscay: a joint French-Spanish project. Geol. Soc. Lond. Spec. Publ 405, 77-113. https://doi.org/10.1144/sp405.13.

Borradaile, G.J., Jackson, M., 2004. Anisotropy of magnetic susceptibility (AMS): magnetic petrofabrics of deformed rocks. Geol. Soc. Spec. Publ. 238 (1), 299-360. https://doi.org/10.1144/GSL.SP.2004.238.01.18.

Calvín, P., Casas, A.M., Villalaín, J.J., Tierz, P., 2014. Reverse magnetic anomaly controlled by Permian igneous rocks in the Iberian Chain (N Spain). Geol. Acta 12, 193-207. https://doi.org/10.1344/GeologicaActa2014.12.3.2.

Cambeses, A., Montero, P., Molina, J.F., Hyppolito, T., Bea, F., 2018. Constraints of mantle and crustal sources and interaction during orogenesis: a zircon SHRIMP U-Th$\mathrm{Pb}$ and $\mathrm{O}$ isotope study of the 'calc-alkaline' Brovales pluton, Ossa-Morena Zone, Iberian Variscan Belt. Lithos 324-325, 661-683. https://doi.org/10.1016/ j.lithos.2018.11.037.

Crespo-Blanc, A., Orozco, M., 1988. The southern Iberian shear zone: a major boundary in the Hercynian folded belt. Tectonophysics 148, 221-227. https://doi.org/10.1016/ 0040-1951(88)90130-8.

Deenen, M.H.L., Langereis, C.G., van Hinsbergen, D.J.J., Biggin, A.J., 2011. Geomagnetic secular variation and the statistics of palaeomagnetic directions. Geophys. J. Int. 186, 509-520. https://doi.org/10.1111/j.1365-246X.2011.05050.x.

Dekkers, M.J., Passier, H.F., Schoonen, M.A.A., 2000. Magnetic properties of hydrothermally synthesized greigite (Fe3S4)-II. High- and low-temperature characteristics. Geophys. J. Int. 141, 809-819. https://doi.org/10.1046/j.1365246X.2000.00129.x.

Dias da Silva, Í., Gómez-Barreiro, J., Martínez Catalán, J.R., Ayarza, P., Pohl, J., Martínez, E., 2017. Structural and microstructural analysis of the Retortillo Syncline (Variscan belt, Central Iberia). Implications for the Central Iberian Orocline. Tectonophysics 717, 99-115. https://doi.org/10.1016/j.tecto.2017.07.015.

Dias da Silva, Í., González Clavijo, E., Díez-Montes, A., 2020. The collapse of the Variscan belt: a Variscan lateral extrusion thin-skinned structure in NW Iberia. Int. Geol. Rev. https://doi.org/10.1080/00206814.2020.1719544.

Dias da Silva, Í., Pereira, M.F., Silva, J.B., Gama, C., 2018. Time-space distribution of silicic plutonism in a gneiss dome of the Iiberian Variscan Belt: the Évora Massif (Ossa-Morena Zone, Portugal). Tectonophysics 747-748, 298-317. https://doi.org/ 10.1016/j.tecto.2018.10.015

Dias, R., Ribeiro, A., Romão, J., Coke, C., Moreira, N., 2016. A review of the arcuate structures in the Iberian Variscides; constraints and genetic models. Tectonophysics 681, 170-194. https://doi.org/10.1016/j.tecto.2016.04.011.

Díez Fernández, R., Pereira, M.F., 2016. Extensional orogenic collapse captured by strikeslip tectonics: constraints from structural geology and U-Pb geochronology of the Pinhel shear zone (Variscan orogen, Iberian Massif). Tectonophysics 691, 290-310.

Diez-Balda, M.A., 1995. Syn-collisional extensional collapse parallel to the erogenic trend in a domain of steep tectonics: the Salamanca Detachment Zone (Central Iberian Zone, Spain). J. Struct. Geol. 17, 163-182. https://doi.org/10.1016/0191-8141(94) e0042-w.

Domeier, M., 2016. A plate tectonic scenario for the Iapetus and Rheic oceans. Gondwana Res. 36, 275-295. https://doi.org/10.1016/j.gr.2015.08.003.

Domeier, M., Torsvik, T.H., 2014. Plate tectonics in the late Paleozoic. Geosci. Front. 5 303-350. https://doi.org/10.1016/j.gsf.2014.01.002.

Edel, J., Casini, L., Oggiano, G., Rossi, P., Schulmann, K., Cnrs, U.M.R., 2014. Early Permian $90^{\circ}$ clockwise rotation of the Maures -Estérel-Corsica - Sardinia Block confirmed by new palaeomagnetic data and followed by a Triassic $60^{\circ}$ clockwise rotation, vol. 405. Geological Society, London, Special Publications, pp. 333-361.

Eguíluz, L., Ibarguchi, J.I.G., Ábalos, B., Apraiz, A., 2000. Superposed Hercynian and Cadomian orogenic cycles in the Ossa-Morena zone and related areas of the iberian Massif. GSA Bull. 112, 1398-1413. https://doi.org/10.1130/0016-7606(2000) $112<1398$ :shacoc $>2.0$. co; 2 .

Eldredge, S., Bachtadse, V., Van Der Voo, R., 1985. Paleomagnetism and the orocline hypothesis. Tectonophysics 119, 153-179. https://doi.org/10.1016/0040-1951(85) 90037-X.
Faure, M., Lardeaux, J., Ledru, P., 2009. A review of the pre-Permian geology of the Variscan French Massif Central. Compt. Rendus Geosci. 341, 202-213. https:// doi.org/10.1016/j.crte.2008.12.001.

Fernández-lozano, J., Pastor-galán, D., Gutiérrez-alonso, G., Franco, P., 2016. Tectonophysics new kinematic constraints on the Cantabrian orocline: a paleomagnetic study from the Peñalba and Truchas synclines, NW Spain. Tectonophysics 681, 195-208. https://doi.org/10.1016/j.tecto.2016.02.019.

Fernández-Lozano, J., Gutiérrez-Alonso, G., Willingshofer, E., Sokoutis, D., de Vicente, G., Cloetingh, S., 2019. Shaping of intraplate mountain patterns: the Cantabrian orocline legacy in Alpine Iberia. Lithosphere 11, 708-721. https://doi.org/10.1130/L1079.1.

Gordon, R.G., 1998. The plate tectonic approximation: plate nonrigidity, diffuse plate boundaries, and global plate reconstructions. Annu. Rev. Earth Planet Sci. 26, 615-642. https://doi.org/10.1146/annurev.earth.26.1.615.

Gutiérrez-Alonso, G., 1996. Strain partitioning in the footwall of the Somiedo Nappe: structural evolution of the Narcea Tectonic Window, NW Spain. J. Struct. Geol. 18, 1217-1229. https://doi.org/10.1016/S0191-8141(96)00034-X.

Gutiérrez-Alonso, G., Fernández-suárez, J., Weil, A.B., 2004. Orocline triggered lithospheric delamination. In: Sussman, A.J., Weil, A.B. (Eds.), Orogenic Curvature: Integrating Paleomagnetic and Structural Analyses. Geological Society of America Special Paper, vol. 383, pp. 121-130. https://doi.org/10.1130/0-8137-2383-3(2004) 383.

Gutíerrez-Alonso, G., Fernandez-Suarez, J., Weil, A.B., Murphy, J.B., Nance, R.D., Corfú, F., Johnston, S.T., 2008a. Self-subduction of the Pangaean global plate. Nat. Geosci. 1, 549-553. https://doi.org/10.1038/ngeo250.

Gutiérrez-Alonso, G., Murphy, J.B., Fernández-Suárez, J., Hamilton, M.A., 2008b. Rifting along the northern Gondwana margin and the evolution of the Rheic Ocean: a Devonian age for the El Castillo volcanic rocks (Salamanca, Central Iberian Zone). Tectonophysics 461, 157-165. https://doi.org/10.1016/j.tecto.2008.01.013.

Gutiérrez-Alonso, G., Murphy, J.B., Fernández-suárez, J., Weil, A.B., Franco, M.P., Gonzalo, J.C., 2011. Lithospheric delamination in the core of Pangea: Sm-Nd insights from the Iberian mantle. Geology 39, 155-158. https://doi.org/10.1130/G31468.1.

Gutíerrez-Alonso, G., Johnston, S.T., Weil, A.B., Pastor-Galán, D., Fernandez-Suarez, J., 2012. Buckling an orogen: the Cantabrian Orocline. GSA Today (Geol. Soc. Am.) 22 (7), 4-9. https://doi.org/10.1130/GSATG141A.1.

Gutiérrez-Alonso, G., Collins, A.S., Fernández-Suárez, J., Pastor-Galán, D., GonzálezClavijo, E., Jourdan, F., Weil, A.B., Johnston, S.T., 2015. Dating of lithospheric buckling: ${ }^{40} \mathrm{Ar} /{ }^{39} \mathrm{Ar}$ ages of syn-orocline strike-slip shear zones in northwestern Iberia. Tectonophysics 643, 44-54. https://doi.org/10.1016/j.tecto.2014.12.009.

Gutiérrez-Alonso, G., Fernández-Suárez, J., López-Carmona, A., Gärtner, A., 2018. Exhuming a cold case: the early granodiorites of the northwest Iberian Variscan belt-a Visean magmatic flare-up? Lithosphere 10 (2), 194-216. https://doi.org/ 10.1130/L706.1.

Gutiérrez-Marco, J.C., Piçarra, J.M., Meireles, C.A., Cózar, P., García-Bellido, D.C., Pereira, Z., Vaz, N., Pereira, S., Lopes, G., Oliveira, J.T., Quesada, C., Zamora, S. Esteve, J., Colmenar, J., Bernárdez, E., Coronado, I., Lorenzo, S., Sá, A.A., Dias da Silva, I., González-Clavijo, E., Díez-Montes, A., Gómez-Barreiro, J., 2019. Early Ordovician-Devonian Passive Margin Stage in the Gondwanan Units of the Iberian Massif. In: Quesada, C., Oliveira, J. (Eds.), The Geology of Iberia: A Geodynamic Approach. Regional Geology Reviews. Springer, Cham, pp. 75-98.

Hatcher, R., 2010. The Appalachian orogen: a brief summary, from Rodinia to Pangea: the lithotectonic record of the Appalachian region. Geol. Soc. Am., Mem. 206, 1-19. https://doi.org/10.1130/2010.1206(01).

Hirt, A.M., Lowrie, W., Clendenen, W.S., Kligfield, R., 1993. Correlation of strain and the anisotropy of magnetic susceptibility in the Onaping Formation: evidence for a nearcircular origin of the Sudbury Basin. Tectonophysics 225, 231-254.

Izquierdo-Llavall, E., Roca, E., Xie, H., Pla, O., Muñoz, J.A., Rowan, M.G., Yuan, N., Huang, S., 2018. Influence of overlapping décollements, syntectonic sedimentation, and structural inheritance in the evolution of a contractional system: the central Kuqa fold-and-thrust belt (Tian Shan Mountains, NW China). Tectonics 37, 2608-2632. https://doi.org/10.1029/2017TC004928.

Jacques, D., Muchez, P., Sintubin, M., 2018a. Tectonophysics superimposed folding and W-Sn vein-type mineralisation in the Central Iberian Zone associated with lateVariscan oroclinal buckling: a structural analysis from the Regoufe area (Portugal). Tectonophysics 742-743, 66-83. https://doi.org/10.1016/j.tecto.2018.05.021.

Jacques, D., Vieira, R., Muchez, P., Sintubin, M., 2018b. Transpressional folding and associated cross-fold jointing controlling the geometry of post-orogenic vein-type WSn mineralization: examples from Minas da Panasqueira, Portugal. Miner. Deposita 53, 171-194. https://doi.org/10.1007/s00126-017-0728-6.

Jesus, A.P., Mateus, A., Munhá, J.M., Tassinari, C.C., dos Santos, T.M.B., Benoit, M., 2016. Evidence for underplating in the genesis of the Variscan synorogenic Beja Layered Gabbroic Sequence (Portugal) and related mesocratic rocks. Tectonophysics 683 148-171. https://doi.org/10.1016/j.tecto.2016.06.001.

Johnston, S.T., Weil, A.B., Gutiérrez-Alonso, G., 2013. Oroclines: thick and thin. Geol. Soc. Am. Bull. 125 (5-6), 643-663. https://doi.org/10.1130/B30765.1.

Julivert, M., Fontboté, J., Ribeiro, A., 1974. Memoria explicativa del mapa tectónico de la Península Ibérica y Baleares. IGME 1, 13 (in Spanish).

Koymans, M.R., Langereis, C.G., Pastor-Galán, D., Hinsbergen, D.J., 2016. Paleomagnetism.org: an online multi-platform open source environment for paleomagnetic data analysis. Comput. Geosci. 93, 127-137. https://doi.org/ 10.1016/j.cageo.2016.05.007.

Kirschvink, J.L., 1980. The least-squares line and plane and the analysis of palaeomagnetic data. Geophys. J. Int. 62 (3), 699-718.

Koymans, M.R., Hinsbergen, D.J., Pastor-Galan, D., Vaes, B., Langereis, C.G., 2020 Towards FAIR paleomagnetic data management through Paleomagnetism.org 2.0. 
Geochemistry, Geophysics. Geosystems 21, e2019GC008838. https://doi.org 10.1029/2019gc008838.

Langereis, G., Krijgsman, W., Muttoni, G., Menning, M., 2010. Magnetostratigraphyconcepts, definitions, and applications. Newsl. Stratigr. 43, 207-233. https://doi.org/ 10.1127/0078-0421/2010/0043-0207.

Li, P., Rosenbaum, G., Donchak, P.J.T., 2012. Structural evolution of the Texas Orocline, eastern Australia. Gondwana Res. 22, 279-289. https://doi.org/10.1016/ j.gr.2011.09.009.

Liñán, E., Quesada, C., 1990. Ossa-Morena zone: rift phase (Cambrian). In: Dallmeyer, R.D., Garcia, E.M. (Eds.), Pre-Mesozoic Geology of Iberia. Springer, Berlin, Heidelberg, pp. 259-266.

Linnemann, U., Pereira, M.F., Jeffries, T.E., Drost, K., Gerdes, A., 2008. The Cadomian Orogeny and the opening of the Rheic Ocean: the diacrony of geotectonic processes constrained by LA-ICP-MS U-Pb zircon dating (Ossa-Morena and saxo-thuringian zones, Iberian and Bohemian massifs). Tectonophysics 461, 21-43. https://doi.org/ 10.1016/j.tecto.2008.05.002

López-Carmona, A., Abati, J., Pitra, P., Lee, J.W., 2014. Retrogressed lawsonite blueschists from the NW Iberian Massif: P-T-t constraints from thermodynamic modelling and ${ }^{40} \mathrm{Ar} /{ }^{39} \mathrm{Ar}$ geochronology. Contrib. Mineral. Petrol. 167, 1-20. https:// doi.org/10.1007/s00410-014-0987-5.

López-Moro, F.J., López-Plaza, M., Gutiérrez-Alonso, G., Fernández-Suárez, J., LópezCarmona, A., Hofmann, M., Romer, R.L., 2018. Crustal melting and recycling: geochronology and sources of Variscan syn-kinematic anatectic granitoids of the Tormes Dome (Central Iberian Zone). A U-Pb LA-ICP-MS study. Int. J. Earth Sci. 107, 985-1004. https://doi.org/10.1007/s00531-017-1483-8.

Lorenz, V., Nicholls, I.A., 1984. Plate and intraplate processes of Hercynian Europe during the late Paleozoic. Tectonophysics 107, 25-56.

Mac Niocaill, C., 2000. A new Silurian palaeolatitude for eastern Avalonia and evidence for crustal rotations in the Avalonian margin of southwestern Ireland. Geophys. J. Int. 141, 661-671. https://doi.org/10.1046/j.1365-246X.2000.00101.x.

Marshak, S., 2004. Salients, recesses, arcs, oroclines, and syntaxes - a review of ideas concerning the formation of map-view curves in fold-thrust belts. AAPG Memoir 82, $131-156$

Martínez-Catalán, J.R., 2011. Are the oroclines of the Variscan belt related to late Variscan strike-slip tectonics? Terra. Nova 23 (4), 241-247. https://doi.org/ 10.1111/j.1365-3121.2011.01005.x.

Martínez-Catalán, J.R., 2012. The Central Iberian arc, an orocline centered in the Iberian Massif and some implications for the Variscan belt. International Journal of Earth Sciences 1299-1314. https://doi.org/10.1007/s00531-011-0715-6.

Martínez-Catalán, J.R., Arenas, R., Abati, J., Martínez, S.S., García, F.D., Suárez, J.F. Cuadra, P.G., Castiñeiras, P., Barreiro, J.G., Montes, A.D., Clavijo, E.G., 2009. A rootless suture and the loss of the roots of a mountain chain: the Variscan belt of NW Iberia. Compt. Rendus Geosci. 341 (2-3), 114-126.

Martínez-Catalán, J.R., Gómez Barreiro, J., Dias da Silva, Í., Chichorro, M., LópezCarmona, A., Castiñeiras, P., Abati, J., Andonaegui, P., Fernández-Suárez, J. González Cuadra, P., Benítez-Pérez, J.M., 2019. Variscan Suture Zone and Suspect Terranes in the NW Iberian Massif: Allochthonous Complexes of the Galicia-Trás os Montes Zone (NW Iberia). In: Quesada, C., Oliveira, J.T. (Eds.), The Geology of Iberia: A Geodynamic Approach. Regional Geology Reviews. Springer, Cham, pp. 99-130. https://doi.org/10.1007/978-3-030-10519-8_4.

Martínez-Catalán, J., Rubio Pascual, F., Diez Montes, A., Diez-Fernandez, R., GomezBarreiro, J., Dias da Silva, Í.F., González-Clavijo, E., Ayarza, P., Alcock, J.E., 2014. The late Variscan HT / LP metamorphic event in NW and Central Iberia: relationship to crustal thickening, extension, orocline development and crustal evolution. Geol. Soc. Spec. Publ., pp. 225-247

Martínez-García, E., 2013. An Alleghenian orocline: the Asturian Arc, northwestern Spain Int. Geol. Rev. 55 (3), 367-381. https://doi.org/10.1080/00206814.2012.713544.

McFadden, P., McElhinny, M., 1987. The combined analysis of remagnetization circles and direct observations in palaeomagnetism. Earth Planet Sci. Lett. 87, 161-172.

Meijers, M.J.M., Smith, B., Pastor-Galán, D., Degenaar, R., Sadradze, N., Adamia, S., Sahakyan, L., Avagyan, A., Sosson, M., Rolland, Y., Langereis, C.G., Müller, C., 2017. Progressive Orocline formation in the Eastern Pontides-Lesser Caucasus. Geol. Soc. Spec. Publ. 428, 117-143. https://doi.org/10.1144/SP428.8.

Merino-Tomé, O.A., Bahamonde, J.R., Colmenero, J.R., Heredia, N., Villa, E., Farias, P. 2009. Emplacement of the Cuera and Picos de Europa imbricate system at the core of the Iberian-Armorican arc (Cantabrian zone, north Spain): new precisions concerning the timing of arc closure. Bull. Geol. Soc. Am. 121, 729-751. https://doi.org/ $10.1130 / \mathrm{B} 26366.1$

Moita, P., Munhá, J., Fonseca, P., Pedro, J., Araújo, A., Tassinari, C., Palacios, T., 2005 Phase equilibria and geochronology of Ossa-Morena eclogites. Lecture in Universidade de Évora. http://hdl.handle.net/10174/2299.

Mullender, T.A.T. Velzen, A.J. Van, Dekkers, M.J., 1993. Continuous drift correction and separate identification of ferrimagnetic and paramagnetic contributions in thermomagnetic runs. Geophys. J. Int. 663-672.

Mullender, T.A.T., Frederichs, T., Hilgenfeldt, C., de Groot, L.V., Fabian, K., Dekkers, M.J., 2016. Automated paleomagnetic and rock magnetic data acquisition with an in-line horizontal "2G" system. Geochemistry, Geophysics. Geosystems 17, 3546-3559. https://doi.org/10.1002/2016GC006436.

Munhá, J., Oliveira, J., Ribeiro, A., Oliveira, V., Quesada, C., Kerrich, R., 1986. BejaAcebuches Ophiolite: characterization and geodynamic significance. Maleo. Bol. Inf. Soc. Geol. Port 2 (13), 1-31.

Munhá, J., Ribeiro, A., Fonseca, P., Oliveira, J.T., Castro, P., Quesada, C., 1989. Accreted terranes in Southern Iberia: Beja-Acebuches ophiolite and related oceanic sequences. In: 28th Inter. Geol. Congr., pp. 481-482. Washington, DC.

Murphy, J.B., Quesada, C., Gutiérrez-Alonso, G., Johnston, S.T., Weil, A., 2016. Reconciling competing models for the tectono-stratigraphic zonation of the Variscan orogen in Western Europe. Tectonophysics 681, 209-219. https://doi.org/10.1016/ j.tecto. 2016.01.006.

Nance, R.D., Gutiérrez-Alonso, G., Keppie, J.D., Linnemann, U., Murphy, J.B., Quesada, C., Strachan, R.A., Woodcock, N.H., 2010. Evolution of the Rheic ocean. Gondwana Res. 17, 194-222. https://doi.org/10.1016/j.gr.2009.08.001.

Oliveira, H., Dias Da Silva, I., Almeida, P., 2007. Tectonic and stratigraphic description and mapping of the Santa Susana Shear Zone (SSSZ), the SW Border of Ossa Morena Zone (OMZ), Barrancão - Ribeira de S. Cristóvão Sector (Portugal): theoretical implications. Geogaceta 41, 151-154.

Oliveira, J.T., González-Clavijo, E., Alonso, J., Aremandáriz, M., Bahamonde, J.R., Braid, J.A., Colmenero, J.R., Dias da Silva, Í., Fernandes, P., Fernández, L.P., Gabaldón, V., Jorge, R.S., Machado, G., Marcos, A., Merino-Tomé, O., Moreira, N., Murphy, J.B., Pinto de Jesus, A., Quesada, C., Rodrigues, B., Rosales, I., SanzLópez, J., Suárez, A., Villa, E., Piçarra, J.M., Pereira, Z., 2019a. Synorogenic Basins. In: Quesada, C., Oliveira, J. (Eds.), The Geology of Iberia: A Geodynamic Approach. Regional Geology Reviews. Springer, Cham, pp. 349-429.

Oliveira, J.T., Quesada, C., Pereira, Z., Matos, J.X., Solá, A.R., Rosa, D., Albardeiro, L., Díez-Montes, A., Morais, I., Inverno, C., Rosa, C., Relvas, J., 2019b. South Portuguese Terrane: A Continental Affinity Exotic Unit. In: Quesada, C., Oliveira, J. (Eds.), The Geology of Iberia: A Geodynamic Approach. Regional Geology Reviews. Springer, Cham, pp. 173-206.

Onézime, J., Charvet, J., Faure, M., Chauvet, A., Panis, D., 2002. Structural evolution of the southernmost segment of the West European variscides: the South Portuguese zone (SW Iberia). J. Struct. Geol. 24, 451-468. https://doi.org/10.1016/S01918141(01)00079-7.

O'Brien, T.M., van der Pluijm, B.A., 2012. Timing of Iapetus Ocean rifting from Ar geochronology of pseudotachylytes in the St. Lawrence rift system of southern Quebec. Geology 40, 443-446. https://doi.org/10.1130/G32691.1.

Osete, M.L., Rey, D., Villalaín, J.J., Juárez, M.T., 1997. The Late Carboniferous to Late Triassic segment of the apparent polar wander path of Iberia. Geologie en Mijnbouw 76, 105-119.

Palero-Fernández, F.J., Martin-Izard, A., Zarzalejos, M., Mansilla-Plaza, L., 2014 Geological context and plumbotectonic evolution of the giant Almadén Mercury Deposit. Ore Geol. Rev. 64, 71-88. https://doi.org/10.1016/ j.oregeorev.2014.06.013.

Parés, J.M., 2015. Sixty years of anisotropy of magnetic susceptibility in deformed sedimentary rocks. Front. Earth Sci. 3, 1-13. https://doi.org/10.3389/ feart.2015.00004.

Parés, J.M., van der Voo, R., 1992. Paleozoic paleomagnetism of Almaden, Spain: a cautionary note. J. Geophys. Res. 97, 9353-9356.

Pastor-Galán, D., Groenewegen, T., Brouwer, D., Krijgsman, W., Dekkers, M.J., 2015a. One or two oroclines in the Variscan orogen of Iberia? Implications for Pangea amalgamation. Geology 43 (6), 527-530. https://doi.org/10.1130/G36701.1.

Pastor-Galán, D., Gutiérrez-Alonso, G., Meere, P.A., Mulchrone, K.F., 2009. Factor affecting finite strain estimation in low-grade, low-strain clastic rocks. J. Struct. Geol. 31, 1586-1596. https://doi.org/10.1016/j.jsg.2009.08.005.

Pastor-Galán, D., Gutiérrez-Alonso, G., Weil, A.B., 2011. Orocline timing through joint analysis: insights from the Ibero-Armorican Arc. Tectonophysics 507 (1-4), 31-46. https://doi.org/10.1016/j.tecto.2011.05.005.

Pastor-Galán, D., Gutiérrez-Alonso, G., Zulauf, G., Zanella, F., 2012. Analogue modeling of lithospheric-scale orocline buckling: constraints on the evolution of the IberianArmorican arc. Bull. Geol. Soc. Am. 124, 1293-1309. https://doi.org/10.1130/ B30640.1.

Pastor-Galán, D., Langereis, C.G., Gutiérrez-Alonso, G., 2017a. Paleomagnetism in Extremadura (Central Iberian zone, Spain) Paleozoic rocks : extensive remagnetizations and further constraints on the extent of the Cantabrian orocline. J. Iber. Geol. 43, 583-600. https://doi.org/10.1007/s41513-017-0039-x.

Pastor-Galán, D., Martín-Merino, G., Corrochano, D., 2014. Tectonophysics timing and structural evolution in the limb of an orocline: the Pisuerga - Carrión Unit (southern limb of the Cantabrian Orocline, NW Spain). Tectonophysics 622, 110-121. https:// doi.org/10.1016/j.tecto.2014.03.004.

Pastor-Galán, D., Dekkers, M.J., Gutiérrez-Alonso, G., Brouwer, D., Groenewegen, T. Krijgsman, W., Fernández-Lozano, J., Yenes, M., Álvarez-Lobato, F., 2016. Paleomagnetism of the Central Iberian curve's putative hinge: too many oroclines in the Iberian Variscides. Gondwana Res. 39, 96-113. https://doi.org/10.1016/ j.gr.2016.06.016.

Pastor-Galán, D., Mulchrone, K.F., Koymans, M.R., van Hinsbergen, D.J.J., Langereis, C.G., 2017b. Bootstrapped total least squares orocline test: a robust method to quantify vertical-axis rotation patterns in orogens, with examples from the Cantabrian and Aegean oroclines. Lithosphere 9, 499-511. https://doi.org/10.1130/ L547.1.

Pastor-Galán, D., Pueyo, E.L., Diederen, M., Garcia-Lasanta, C., Langereis, C.G., 2018. Late Paleozoic Iberian Orocline(s) and the missing shortening in the core of Pangea. Paleomagnetism from the Iberian Range. Tectonics 37, 3877-3892. https://doi.org/ 10.1029/2018TC004978.

Pastor-Galán, D., Dias da Silva, Í.F., Groenewegen, T., Krijgsman, W., 2019. Tangled up in folds: tectonic significance of superimposed folding at the core of the Central Iberian curve (West Iberia). Int. Geol. Rev. 61 (2), 240-255. https://doi.org/10.1080/ 00206814.2017 .1422443

Pastor-Galán, D., Gutiérrez-Alonso, G., Weil, A.B., 2020. The enigmatic curvature of Central Iberia and its puzzling kinematics. Solid Earth 11, 1247-1273. https:// doi.org/10.5194/se-11-1247-2020.

Pereira, M.F., Solá, A.R., Chichorro, M., Lopes, L., Gerdes, A., Silva, J.B., 2012a. NorthGondwana assembly, break-up and paleogeography: U-Pb isotope evidence from detrital and igneous zircons of Ediacaran and Cambrian rocks of SW Iberia. Gondwana Res. 22, 866-881. https://doi.org/10.1016/j.gr.2012.02.010. 
Pereira, M.F., Chichorro, M., Johnston, S., Gutiérrez-Alonso, G., Silva, J., Linnemann, U., Hofmann, M., Drost, K., 2012b. The missing Rheic ocean magmatic arcs: provenance analysis of Late Paleozoic sedimentary clastic rocks of SW Iberia. Gondwana Res. 22, 882-891.

Pastor-Galán, D., Ursem, B., Meere, P.A., Langereis, C., 2015b. Extending the Cantabrian Orocline to two continents (from Gondwana to Laurussia). Paleomagnetism from South Ireland. Earth Planet Sci. Lett. 432, 223-231. https://doi.org/10.1016/ j.epsl.2015.10.019.

Pereira, M.F., Castro, A., Chichorro, M., Fernández, C., Díaz-Alvarado, J., Martí, J. Rodríguez, C., 2014. Chronological link between deep-seated processes in magma chambers and eruptions: Permo-Carboniferous magmatism in the core of Pangaea (Southern Pyrenees). Gondwana Res. 25, 290-308. https://doi.org/10.1016/ j.gr.2013.03.009.

Pereira, M.F., Castro, A., Fernández, C., 2015. The inception of a Paleotethyan magmatic arc in Iberia. Geosci. Front. 6, 297-306. https://doi.org/10.1016/j.gsf.2014.02.006.

Pereira, M.F., Gutíerrez-Alonso, G., Murphy, J.B., Drost, K., Gama, C., Silva, J.B., 2017. Birth and demise of the Rheic Ocean magmatic arc(s): combined $\mathrm{U}-\mathrm{Pb}$ and Hf isotope analyses in detrital zircon from SW Iberia siliciclastic strata. Lithos 278-281, 383-399. https://doi.org/10.1016/j.lithos.2017.02.009.

Pereira, M.F., Díez Fernández, R., Gama, C., Hofmann, M., Gärtner, A., Linnemann, U., 2018a. S-type granite generation and emplacement during a regional switch from extensional to contractional deformation (Central Iberian Zone, Iberian autochthonous domain, Variscan Orogeny). Int. J. Earth Sci. 107 (1), 251-267.

Pereira, M.F., Martínez Poyatos, D., Pérez-Cáceres, I., Gama, C., Azor, A., 2019. Comment on "Stratigraphy of the Northern Pulo do Lobo Domain, SW Iberia Variscides: a palynological contribution" by Zélia Pereira et al. (2018) - geobios 51, 491-506. Geobios 55, 103-106. https://doi.org/10.1016/j.geobios.2019.06.003.

Pereira, Z., Fernandes, P., Matos, J.X., Jorge, R.C.G.S., Oliveira, J.T., 2018b. Stratigraphy of the Northern Pulo do Lobo Domain, SW Iberia Variscides: a palynological contribution. Geobios 51, 491-506. https://doi.org/10.1016/j.geobios.2018.04.001.

Pereira, M.F., Gama, C., Dias da Silva, Í., Fuenlabrada, J.M., Silva, J.B., Medina, J., 2020 Isotope geochemistry evidence for Laurussian-type sources of South-Portuguese Zone Carboniferous turbidites (Variscan orogeny). Geological Society. https://doi.org/ 10.1144/sp503-2019-16. London, Special Publications 503, SP503-2019-2163.

Pérez-Cáceres, I., Martínez Poyatos, D., Simancas, J.F., Azor, A., 2015. The elusive nature of the Rheic Ocean suture in SW Iberia. Tectonics 34, 2429-2450. https://doi.org/ 10.1002/2015TC003947.

Pérez-Cáceres, I., Simancas, J.F., Martínez Poyatos, D., Azor, A., González Lodeiro, F., 2016. Oblique collision and deformation partitioning in the SW Iberian Variscides. Solid Earth 7, 857-872. https://doi.org/10.5194/se-7-857-2016.

Pérez-Cáceres, I., Martínez Poyatos, D., Simancas, J.F., Azor, A., 2017. Testing the Avalonian affinity of the South Portuguese Zone and the Neoproterozoic evolution of SW Iberia through detrital zircon populations. Gondwana Res. 42, 177-192. https:// doi.org/10.1016/j.gr.2016.10.010.

Perroud, H., Bonhommet, M., Ribeiro, A., 1985. The Upper Devonian Beja gabbro yields. Geophys. Res. Lett. 12, 45-48.

Perroud, H., Calza, F., Khattach, D., 1991. Paleomagnetism of the Silurian volcanism at Almaden, southern Spain. J. Geophys. Res. 96, 1949-1962.

Pin, C., Fonseca, P.E., Paquette, J.L., Castro, P., Matte, P., 2008. The ca. 350 Ma Beja Igneous Complex: a record of transcurrent slab break-off in the southern Iberia Variscan Belt? Tectonophysics 461, 356-377. https://doi.org/10.1016/ j.tecto.2008.06.001.

Pueyo, E.L., Pocoví, A., Parés, J.M., Millán, H., Larrasoana, J.C., 2003. Thrust ramp geometry and spurious rotations of paleomagnetic vectors. Studia Geophys. Geod. 47 331-357. https://doi.org/10.1023/A:1023775725268.

Pueyo, E.L., Sussman, A.J., Oliva-Urcia, B., Cifelli, F., 2016. Palaeomagnetism in fold and thrust belts: use with caution. Geol. Soc. Spec. Publ. 425, 259-276. https://doi.org/ 10.1144/SP425.14.

Quesada, C., 1996. A reappraisal of the structure of the Spanish segment of the Iberian Pyrite Belt. Miner. Deposita 31-44.

Quesada, C., Dallmeyer, D.R., 1994. Tectonothermal evolution of the Badajoz-Cordóba shear zone (SW Iberia): characteristics and ${ }^{40} \mathrm{Ar} /{ }^{39} \mathrm{Ar}$ mineral age constraints. Tectonophysics 231 (1-3), 195-213.

Quesada, C., Braid, J.A., Fernandes, P., Ferreira, P., Jorge, R.S., Matos, J.X., Murphy, J.B., Oliveira, J.T., Pedro, J., Pereira, Z., 2019. SW Iberia Variscan Suture Zone: oceanic affinity units. In: Quesada, C., Oliveira, J. (Eds.), The Geology of Iberia: A Geodynamic Approach. Regional Geology Reviews. Springer, Cham, pp. 131-171.

Rezaeian, M., Kuijper, C.B., van der Boon, A., Pastor-Galán, D., Cotton, L.J., Langereis, C.G., Krijgsman, W., 2020. Post-Eocene coupled oroclines in the Talesh (NW Iran): paleomagnetic constraints. Tectonophysics 786, 228459.

Ribeiro, A., Munhá, J., Dias, R., Mateus, A., Pereira, E., Ribeiro, L., Fonseca, P., Araújo, A., Oliveira, T., Romão, J., Chaminé, H., Coke, C., Pedro, J., 2007. Geodynamic evolution of the SW Europe Variscides. Tectonics 26, 1-24. https://doi.org/10.1029/ 2006TC002058.

Ries, A.C., Shackleton, R.M., 1976. Patterns of strain variation in arcuate fold belts. Phil. Trans. Roy. Soc. Lond. Math. Phys. Sci. 283, 281-288. https://doi.org/10.2307/ 74645.

Robardet, M., Doré, F., 1988. The Late Orodovician Diamictitic Formations from Southwestern Europe: North-Gondwana glaciomarine deposits. Paleogeography 66, 19-31.

Rosas, F.M., Marques, F.O., Ballèvre, M., Tassinari, C., 2008. Geodynamic evolution of the SW Variscides: Orogenic collapse shown by new tectonometamorphic and isotopic data from western Ossa-Morena Zone, SW Iberia. Tectonics 27. https://doi.org/ 10.1029/2008tc002333. TC6008.

Rubio Pascual, F.J., López-Carmona, A., Arenas, R., 2016. Thickening vs. extension in the Variscan belt: P-T modelling in the Central Iberian autochthon. Tectonophysics 681 , 144-158. https://doi.org/10.1016/j.tecto.2016.02.033.

Sánchez-García, T., Bellido, F., Pereira, M.F., Chichorro, M., Quesada, C., Pin, C., Silva, J.B., 2010. Rift-related volcanism predating the birth of the Rheic ocean (OssaMorena zone, SW Iberia). Gondwana Res. 17, 392-407. https://doi.org/10.1016/ j.gr.2009.10.005.

Sánchez-García, T., Chichorro, M., Solá, A.R., Álvaro, J.J., Díez-Montes, A., Bellido, F., Ribeiro, M.L., Quesada, C., Lopes, J.C., Dias da Silva, Í., González-Clavijo, E., Gómez Barreiro, J., López-Carmona, A., 2019. The Cambrian-Early Ordovician Rift Stage in the Gondwanan Units of the Iberian Massif. In: Quesada, C., Oliveira, J. (Eds.), The Geology of Iberia: A Geodynamic Approach. Regional Geology Reviews. Springer, Cham, pp. 27-74.

Sánchez-García, T., Bellido, F., Quesada, C., 2003. Geodynamic setting and geochemical signatures of Cambrian-Ordovician rift-related igneous rocks (Ossa-Morena Zone, SW Iberia). Tectonophysics 365, 233-255. https://doi.org/10.1016/S0040-1951(03) 00024-6.

Sánchez-Lorda, M.E., Ábalos, B., García de Madinabeitia, S., Eguíluz, L., Gil Ibarguchi, J.I., Paquette, J.L., 2016. Radiometric discrimination of pre-Variscan amphibolites in the Ediacaran Serie Negra (Ossa-Morena zone, SW Iberia). Tectonophysics 681, 31-45. https://doi.org/10.1016/j.tecto.2015.09.020.

Sandoval, L., Welford, J.K., Macmahon, H., Peace, A.L., 2019. Determining continuous basins across conjugate margins: The East Orphan, Porcupine, and Galicia Interior basins of the southern North Atlantic Ocean. Mar. Petrol. Geol. 110, 138-161. https://doi.org/10.1016/j.marpetgeo.2019.06.047.

Schwartz, S.Y., Van der Voo, R., 1983. Paleomagnetic evaluation of the Orocline Hypothesis in the central and southern Appalachians. Geophys. Res. Lett. 10, 505-508. https://doi.org/10.1029/GL010i007p00505.

Shaw, J., Johnston, S.T., 2016. Oroclinal buckling of the Armorican ribbon continent: an alternative tectonic model for Pangean amalgamation and Variscan orogenesis. Lithosphere 8, 769-777. https://doi.org/10.1130/L559.1.

Shaw, J., Johnston, S.T., Gutiérrez-alonso, G., Weil, A.B., 2012. Oroclines of the Variscan orogen of Iberia: paleocurrent analysis and paleogeographic implications. Earth Planet Sci. Lett. 329-330, 60-70. https://doi.org/10.1016/j.epsl.2012.02.014.

Simancas, J.F., Tahiri, A., Azor, A., Martı, D.J., El, H., 2005. The tectonic frame of the Variscan - Alleghanian orogen in Southern Europe and Northern Africa. Tectonophysics 398, 181-198. https://doi.org/10.1016/j.tecto.2005.02.006.

Simancas, J.F., Ayarza, P., Azor, A., Carbonell, R., Poyatos, D.M., Lodeiro, F.G., 2013. A seismic geotraverse across the Iberian Variscides: orogenic shortening, collisional magmatism, and orocline development. Tectonics 32, 417-432. https://doi.org/ 10.1002/tect.20035.

Snowball, I.F., 1997. Gyroremanent magnetization and the magnetic properties of greigite-bearing clays in southern Sweden. Geophys. J. Int. 129 (3), 624-636.

Stampfli, G.M., Hochard, C., Vérard, C., Wilhem, C., von Raumer, J., 2013. The formation of Pangea. Tectonophysics 593, 1-19. https://doi.org/10.1016/j.tecto.2013.02.037.

Staub, R., 1927. Ideas sobre la tectónica de España. Córdoba. Real Academia de Ciencias, Bellas Letras, y Nobles Artes de Córdoba - España (in Spanish).

Tait, J.A., Bachtadse, V., Soffel, H., 1996. Eastern Variscan fold belt: paleomagnetic evidence for oroclinal bending. Geology 24, 871-874. https://doi.org/10.1130/ 0091-7613(1996)024<0871:EVFBPE > 2.3.CO;2.

Tauxe, L., 2010. Essentials of Paleomagnetism. Cambridge University Press, Cambridge, p. 512 .

Thomas, W.A., 1977. Evolution of Appalachain-Ouachita salients and recesses from reentrants and promontories in the continental margin. Am. J. Sci. 277, 1239-1278.

Torsvik, T.H., Voo, R., Preeden, U., Mac, C., Steinberger, B., Doubrovine, P.V., Hinsbergen, D.J., Domeier, M., Gaina, C., Tohver, E., Meert, J.G., Mccausland, P.J.A., Cocks, L.R.M., 2012. Phanerozoic polar wander, palaeogeography and dynamics. Earth Sci. Rev. 114, 325-368. https://doi.org/10.1016/j.earscirev.2012.06.007.

Valladares, M.I., Barba, P., Ugidos, J.M., Colmenero, J.R., Armenteros, I., 2000. Upper Neoproterozoic - Lower Cambrian sedimentary successions in the Central Iberian Zone (Spain): sequence stratigraphy, petrology and chemostratigraphy. Implications for other European zones. Int. J. Earth Sci. 89, 2-20.

van der Boon, A., van Hinsbergen, D.J.J., Rezaeian, M., Gürer, D., Honarmand, M., PastorGalán, D., Krijgsman, W., Langereis, C.G., 2018. Quantifying Arabia-Eurasia convergence accommodated in the Greater Caucasus by paleomagnetic reconstruction. Earth Planet Sci. Lett. 482, 454-469. https://doi.org/10.1016/ j.epsl.2017.11.025.

van der Voo, R., 1969. Paleomagnetic evidence for the rotation of the Iberian Peninsula. Tectonophysics 7, 5-56. https://doi.org/10.1016/0040-1951(69)90063-8.

Velzen, A.J., Zijderveld, J.D.A., 1995. Effects of weathering on single-domain magnetite in Early Pliocene marine marls. Geophys. J. Int. 121, 267-278. https://doi.org/ 10.1111/j.1365-246X.1995.tb03526.x.

Vergés, J., 1983. Estudio del complejo volcano-sedimentario del devónico y de la estructura de la terminación oriental del sinclinal de Almadén (Ciudad Real). In Libro Jubilar J.M. Rios, ume 3. Instituto Geominero de España, Madrid, pp. 215-229 (in Spanish).

Weil, A.B., Sussman, A.J., 2004. Classifying curved orogens based on timing relationships between structural development and vertical-axis rotations. Geol. Soc. Am. Spec. Pap. 3, 1-15. https://doi.org/10.1130/0-8137-2383-3(2004)383.

Weil, A., Gutiérrez-Alonso, G., Conan, J., 2010. New time constraints on lithosphericscale oroclinal bending of the Ibero-Armorican Arc: a palaeomagnetic study of 
earliest Permian rocks from Iberia. J. Geol. Soc. 167, 127-143. https://doi.org/ 10.1144/0016-76492009-002.

Weil, A.B., Gutiérrez-Alonso, G., Johnston, S.T., Pastor-Galán, D., 2013. Tectonophysics kinematic constraints on buckling a lithospheric-scale orocline along the northern margin of Gondwana: a geologic synthesis. Tectonophysics 582, 25-49. https:// doi.org/10.1016/j.tecto.2012.10.006.

Weil, A., Pastor-Galán, D., Johnston, S.T., Gutiérrez-Alonso, G., 2019. Late/Post Variscan orocline formation and widespread magmatism. In: Quesada, C., Oliveira, J. (Eds.),
The Geology of Iberia: A Geodynamic Approach. Regional Geology Reviews. Springer, Cham, pp. 527-542.

Zijderveld, J.D.A., 1967. A. C. Demagnetization of rocks: analysis of results. In: Collinson, D.W., Creer, K.M., Runcorn, S.K. (Eds.), Methods in Paleomagnetism. Developments in Solid Earth Geophysics 3, pp. 254-286. https://doi.org/10.1016/ b978-1-4832-2894-5.50049-5. 